NBER WORKING PAPER SERIES

\title{
DO LOCAL ANALYSTS KNOW MORE? A CROSS-COUNTRY STUDY OF THE PERFORMANCE OF LOCAL ANALYSTS AND FOREIGN ANALYSTS
}

\author{
Kee-Hong Bae \\ René M. Stulz \\ Hongping Tan \\ Working Paper 11697 \\ http://www.nber.org/papers/w11697
NATIONAL BUREAU OF ECONOMIC RESEARCH
1050 Massachusetts Avenue
Cambridge, MA 02138
October 2005

Respectively, Bank of Montreal Associate Professor of Finance, Queen's University, Reese Chair of Banking and Monetary Economics, The Ohio State University, NBER and ECGI, and Ph.D. candidate in finance, Queen's University. We are grateful to Thomson Financial for access to their Institutional Brokers Estimate System (I/B/E/S) provided as part of a broad academic program to encourage earnings expectations research. We also thank Roger Loh for useful comments. The views expressed herein are those of the author(s) and do not necessarily reflect the views of the National Bureau of Economic Research.

C2005 by Kee-Hong Bae, René M. Stulz, and Hongping Tan. All rights reserved. Short sections of text, not to exceed two paragraphs, may be quoted without explicit permission provided that full credit, including (C) notice, is given to the source. 
Do Local Analysts Know More? A Cross-Country Study of the Performance of Local Analysts and Foreign Analysts

Kee-Hong Bae, René M. Stulz, and Hongping Tan

NBER Working Paper No. 11697

October 2005

JEL No. F30, G11, G14, G24

\begin{abstract}
$\underline{\text { ABSTRACT }}$
This paper examines whether analysts resident in a country make more precise earnings forecasts for firms in that country than analysts who are not resident in that country. Using a sample of 32 countries, we find that there is an economically and statistically significant analyst local advantage even after controlling for firm and analyst characteristics. The importance of the local advantage is inversely related to the quality of the information provided by firms. In particular, the local advantage is high in countries where earnings are smoothed more, less information is disclosed by firms, and firm idiosyncratic information explains a smaller fraction of stock returns. The local advantage is also negatively related to market participation by foreign investors and by institutions and positively related to holdings by insiders. U.S. investors underweight a country's stocks more in their portfolios if that country has a higher analyst local advantage.

Kee-Hong Bae

Queen's University

kbae@business.queensu.ca

René M. Stulz

Fisher College of Business, Ohio State University

806A Fisher Hall

2100 Neil Avenue

Columbus, OH 43210-1144

and NBER

stulz@cob.osu.edu

Hongping Tan

Queen's University

ptan@business.queensu.ca
\end{abstract}




\section{Introduction}

Does distance reduce the quality of the information investors have? A large literature investigates the role of distance in investors' portfolio decisions and investment performance. The largest segment of this literature focuses on investors who are separated by borders, but a growing segment investigates the role of distance within countries. Some of the literature concludes that local investors have an advantage. In the international finance literature, it is often believed that at least part of the home bias can be accounted for by the information advantage of local investors. ${ }^{1}$ However, there are also papers that find that foreign investors who participate in a market can be better informed than local investors. In contrast to most studies which focus on investor choices and performance, in this paper we investigate directly whether distance affects the quality of information possessed by one group of market participants, analysts. It is known that in the U.S. analysts who are closer to the headquarters of a firm have an information advantage (Malloy, 2005). We find that local analysts have a significant information advantage over foreign analysts for a large sample of countries.

We investigate the relation between the precision of earnings forecasts of local analysts and of foreign analysts for 32 countries for 2001 through 2003. Our main measure of accuracy for an analyst is the pricescaled absolute forecast error of the analyst minus the average price-scaled absolute forecast error across analysts for the earnings forecasted. We define the local analyst advantage as the difference between the accuracy of local analysts and the accuracy of foreign analysts. If the local analysts have better information, they should predict earnings with more precision. We find that this is the case both for univariate comparisons and when we control for various determinants of forecast accuracy. The difference in the average forecast error in univariate comparisons between local and foreign analysts corresponds to 7.8 percent of the average price-scaled forecast error. When we control for various determinants of the forecast error, the local advantage falls slightly in most cases.

\footnotetext{
${ }^{1}$ See Lewis (1999) and Karolyi and Stulz (2003) for reviews of the literature on the home bias.
} 
Our dataset makes it possible to investigate whether the advantage of local analysts arises because they belong to local brokerage houses which might have established relationships with the local firms they follow or because local analysts are located close to the firms they follow. We consider separately local analysts belonging to local firms and local analysts belonging to foreign firms. We find that there is no difference between the two groups of analysts.

There is considerable variation in the magnitude of the advantage of local analysts. Out of 32 countries, the estimate of the advantage of local analysts is positive in 26 countries and significantly positive in 10 countries. We use this cross-country variation to investigate why local analysts have an advantage.

A plausible explanation for the local advantage is that local analysts have access to information because they are on the spot. They can talk to firm representatives in person. They have access to information by observing what goes on in firms directly. For instance, if a firm is unusually busy, they might observe lots of trucks being loaded. Alternatively, they might talk to employees, customers, competitors. With this explanation, we would expect that the local advantage is inversely related to the quality of the information put forward by the firm. We find that this is strongly the case. Using the S\&P Transparency and Disclosure index, we find a smaller analyst local advantage for firms that have an index value above the sample median. Similarly, the analyst local advantage is significantly lower in countries with above-median accounting transparency. There is no analyst local advantage in countries where earnings management is less prevalent. Further, the local advantage is significantly lower in countries where stock returns incorporate more idiosyncratic information. More precisely, the local advantage is strong in countries where the aggregate stock market return has much explanatory power for individual stock returns as measured by the $\mathrm{R}^{2}$ measure of Morck, Yeung, and $\mathrm{Yu}(2000)$.

The local advantage is closely tied to the quality of disclosure. More disclosure levels the playing field for analysts. Generally, though, countries with low disclosure are also countries with weaker investor protection and poorer financial and economic development. We find that measures of financial development are not associated with the local advantage. One would think that local analysts would be 
better, in that they would have more resources and better training, in countries with greater financial development. Foreign analysts typically belong to firms from developed countries, so that they might have an advantage in resources and training when competing with local analysts in countries with poor financial development. However, if disclosure in such countries is poor, the advantage local analysts obtain from poor disclosure seems to offset the disadvantage associated with poor financial development. Measures of investor rights unrelated to enforcement do not seem to affect the advantage of local analysts.

Does the local advantage contribute to the home bias? Unfortunately, it is not straightforward to answer that question. As Healy and Palepu (2001) emphasize, there is both a demand and a supply for analyst services. Everything else equal, the demand from foreign investors will be less in countries where foreign ownership is smaller and where capital flows are lower. When the demand for analyst services from foreign investors is lower, we would expect fewer resources to be allocated to foreign analysts, so that the local advantage would be higher. Consequently, a non-information based home bias would lead to a local advantage. At the same time, however, information asymmetries that make local analysts better informed and foreign investors less well-informed can, at the same time, reduce the portfolio share of a country in the portfolio of foreign investors and increase the analyst local advantage. To disentangle these effects, we conduct a test that helps distinguish between an increase in the demand for analyst services and an information asymmetry effect and conclude that the information asymmetry is the more powerful effect, so that information asymmetry is a common cause for the analyst local advantage and the home bias.

The paper proceeds as follows. In Section 2, we review the existing literature that addresses issues of distance. In Section 3, we introduce our sample. In Section 4, we present our analyst accuracy measures and univariate comparisons of forecasting accuracy. Section 5 establishes the existence of an advantage for local analysts controlling for firm and analyst characteristics. In Section 6, we investigate the determinants of the analyst local advantage. We turn to the relation between the analyst local advantage and the home bias in Section 7. Section 8 presents various robustness checks. We conclude in Section 9. 


\section{Literature review}

It is well-known that the portfolios of investors are biased towards their home country. There is now a large literature that attempts to explain this home bias. An important strand of this literature emphasizes differences in information between domestic and foreign investors. Early papers that focus on differences in information between domestic and foreign investors include Gehrig (1993) and Kang and Stulz (1997). The assumption that foreign investors are less well-informed is taken as given by Brennan and Cao (1997) in a well-known article where they focus on the implications of this assumption for equity flows. A number of papers attempt to identify more directly whether foreign investors have an information disadvantage. The literature has mixed results. Hau (2001) investigates trading data for professional traders and shows that local investors perform better than foreign traders. Choe, Kho, and Stulz (2005) and Dvorak (2005) find that foreigners trade at worse prices in Korea and Indonesia, respectively. Grinblatt and Keloharju (2000) and Seasholes (2000) argue that better resources and better access to expertise allows foreign institutions to perform better than domestic institutions. Using daily data for the 16 largest Finnish stocks, Grinblatt and Keloharju (2000) find that over a two-year period foreigners and domestic financial corporations buy more stocks that perform well over the next 120 trading days than domestic individual investors. Seasholes (2000) finds that foreign investors buy (sell) ahead of good (bad) earnings announcements in Taiwan while domestic investors do the opposite. Froot, O'Connell, and Seasholes (2001) and Froot and Ramadorai (2001) use flow data to show that foreign investors have some ability to predict returns. These papers are consistent with better information and greater sophistication on the part of foreign investors. However, evidence on the performance of foreign investors is mixed. For instance, Shukla and van Inwegen (1995) show that U.K. money managers underperform American money managers when picking U.S. stocks. Using 18 years of annual data, Kang and Stulz (1997) find no evidence that foreign investors outperform domestic investors in Japan.

More recently, a new literature has developed which looks at the impact of distance on portfolio choice within countries. Coval and Moskowitz (1999), using only U.S. stock returns, provide evidence that investor location matters, in that mutual fund managers overweight the stocks of firms located closer 
to them. In another paper, Coval and Moskowitz (2001) find that mutual fund managers are better at picking stocks of firms that are closer to where they are than stocks of firms from a more distant location. Huberman (2001) finds a local concentration in the ownership of the Baby Bells in the U.S. Ivković and Weisbrenner (2005) use data from a large discount brokerage house and find the striking result that one out of six U.S. individuals in their sample only invest in companies headquartered within 250 miles from the household. Recent papers show that social networks are important for stock holdings. For instance, Hong, Kubik, and Stein (2004) show that mutual fund managers are more likely to hold a particular stock if other managers in the same city are holding the same stock.

A growing number of papers investigate the properties of analyst forecasts across countries. As documented by Chang, Khanna, and Palepu (2000) and others, there is considerable variation across countries in the accuracy of analysts' forecasts. These papers show that country characteristics affect the extent of analyst following and the properties of analyst forecasts. However, these papers seem to provide contradictory results on how the level of investor protection affects analyst accuracy. For instance, while Chang, Khanna, and Palepu (2000) find evidence that a country's legal system helps understand the accuracy of analysts, Ang and Ciccone (2001) reach the opposite conclusion. Hope (2003) finds that the enforcement of accounting standards and firm-level disclosure are important determinants of forecast accuracy.

Only a handful of papers investigate the relation between distance and analyst performance. Malloy (2005) finds evidence that, in U.S., analysts located closer to a firm are more accurate. Bacmann and Bolliger (2001) examine directly the relative performance of analysts from local and foreign brokerage houses for seven Latin American stock markets. They conclude that foreign analysts outperform local analysts. Their study has seven Latin American countries. When they compare the mean difference forecast error between local and foreign analysts, it is not significantly positive for their whole sample, but it is significantly positive for Mexico and Columbia. In contrast, Orpurt (2004) finds evidence of a significant local advantage for a sample of 7 European countries. In his study, local analysts are analysts resident in a country. Hence, these could be domestic or expatriate analysts. He finds that his results are 
driven by Germany. However, while Bolliger (2004) focuses on local versus foreign brokerage houses and finds an advantage for local brokerage houses in Europe, Orpurt (2004) does not find this type of local advantage. Conroy, Fukuda, and Harris (1997) also find a local brokerage house advantage in Japan. Finally, Chang (2003) compares specifically the forecasts of foreign and expatriate analysts for Taiwanese firms. He finds that there is a local advantage, in that expatriate analysts outperform foreign analysts, but then he also finds that expatriate analysts outperform local analysts working for domestic firms. This result is consistent with local analysts working for foreign institutions having the advantage of typically belonging to more sophisticated and resourceful organizations.

\section{The sample.}

Our sample construction begins with the list of firms included in the S\&P's Transparency and Disclosure dataset (hereafter TD dataset). There are several advantages to using the list of firms included in the TD dataset. First, the dataset covers a large sample of firms from over 40 countries allowing us to examine the relation between country-level characteristics and the local analyst advantage. Second, the sample firms in the TD dataset are the largest and better known firms in each of the sample countries and attract much interest from international investors and analysts. Thus, to the extent that there is a bias in our sample construction, the bias leads us to understate the analyst local advantage, since this advantage is likely to be less severe for these firms. Finally, the TD dataset provides a comprehensive firm-level transparency and disclosure measure, which allows us to examine the impact of firm-level disclosure practices on the analyst local advantage. ${ }^{2}$ The dataset provides objective rankings of the corporate reporting practices for firms included in the S\&P Global 1200 index and an additional 400 companies in the Standard \& Poor's/IFCI emerging markets index. S\&P searches company annual reports and standard regulatory filings for the inclusion of the 98 most common disclosure items that fall into one of three categories: financial transparency and information disclosure (35 items), board and management structure

\footnotetext{
${ }^{2}$ Doidge, Karolyi and Stulz (2004), Khanna, Palepu, and Srinivasan (2004), and Durnev and Kim (2005) also use this data source for their measures of firm disclosure and corporate governance.
} 
and process (35 items), and ownership structure and investor relations (28 items). The sample provided to us by Standard and Poor's in September 2004 covers 894 non-U.S firms from 40 countries.

For the list of firms included in the TD dataset, we obtain annual earnings per share forecasts as well as actual annual earnings per share from the $\mathrm{I} / \mathrm{B} / \mathrm{E} / \mathrm{S}$ international files. $\mathrm{I} / \mathrm{B} / \mathrm{E} / \mathrm{S}$ data includes Detail file, Identifier file, Actual file, and Broker Translation file. We then match each analyst's name and brokerage name in $\mathrm{I} / \mathrm{B} / \mathrm{E} / \mathrm{S}$ data with entries from Nelson's Directory of Investment Research by hand. ${ }^{3}$ Nelson's Directory of Investment Research provides information including the analyst's full name and the address, which allows us to tell whether the location of the company that the analyst covers is different from the location of the analyst. ${ }^{4}$ Once we match each analyst's name and brokerage name, we obtain the country location of the analyst and the corresponding country location of the firm that the analyst covers. If the country location of an analyst is the same as that of the firm he covers, we classify the analyst as a local analyst. Otherwise, we classify the analyst as a foreign analyst. Local analysts can be further classified into pure local analysts and expatriate analysts. A pure local analyst is an analyst working for a local research firm, while an expatriate analyst is an analyst working for a research firm from a foreign country.

For the matched sample, we impose several restrictions. First, we select the countries where there are more than 50 firms followed by $\mathrm{I} / \mathrm{B} / \mathrm{E} / \mathrm{S}$ analysts in the $\mathrm{I} / \mathrm{B} / \mathrm{E} / \mathrm{S}$ dataset. This is to ensure that we select the countries that attract a reasonable amount of interest from analysts and international investors. ${ }^{5}$ Second, we select the most recent earnings forecast for each analyst analyzing each firm in each year. Finally, we select only the firms that are followed by both local and foreign analysts. ${ }^{6}$ Without this restriction, we could pick up the effect of firm characteristics to the extent that local and foreign analysts follow firms with different characteristics. It is important to note that this restriction implies that, since we are studying

\footnotetext{
${ }^{3}$ The major difficulty with the matching procedure is that, in some rare cases, we have duplicate matches that have exactly the same analyst and broker names. We exclude duplicate matches. However, the results are almost identical when we include these duplicate matches in the final sample.

${ }^{4}$ Each volume of Nelson's Directory of Investment Research in year $t$ compiles the data using analyst information as of November in year t-1. We classify an analyst's location for year $t$ using information in the Nelson's Directory starting in November of year $t$ through October of year $t+1$.

${ }^{5}$ We drop six countries: Colombia, Greece, Pakistan, Peru, Turkey, and Venezuela.

${ }^{6}$ The results without imposing these restrictions are similar. We provide the robustness tests in Table 9.
} 
the local advantage only for firms which are also followed by foreign analysts, our analysis is likely to understate the extent of the local advantage across all firms since one would expect that foreign analysts would stay away from firms where the local advantage is highest. With this restriction, we lose 155 firms. Eight of these firms are only covered by foreign analysts and the rest are only covered by local analysts. Adding these firms to our main regression does not affect our conclusion as to the existence of analyst local advantage.

Table 1 provides data on our sample. Our Standard \& Poor's TD scores to quantify firm-level information disclosure are based on information as of June 2002. While it seems reasonable to assume that data reported at that time might still describe firm disclosure policies for a few years before, it would be less reasonable to make this assumption going back further in the past. We therefore use 2001-2003 as our sample years. Our final sample contains 2,563 local and 1,920 foreign analysts providing a total of 20,425 annual earnings forecasts on 611 firms from 32 countries. The table shows that, not surprisingly, there is considerable variation across countries in the number of firms in our sample. While the smallest number of firms is 2 for Austria, the largest is 118 for the U.K. The number of local and foreign analysts also varies substantially. While Austria has 3 local analysts, the U.K. has 690. The variation in the number of foreign analysts is also considerable, with South Africa having 11 foreign analysts and France having 526.

The last column of Table 1 shows that the ratio of the number of foreign analysts to the number of distinct analysts varies sharply across countries as well. The lowest ratio is 0.12 for Japan and the highest is 0.91 for China. China has 67 foreign analysts in the sample, but only 7 local analysts. Only 10 countries have a ratio below 0.5 . Consequently, in many of our sample countries there are more foreign analysts than local analysts.

\section{Analyst precision: Univariate comparisons of local, expatriate, and foreign analysts}

Forecast accuracy is one of the most important dimensions along which financial analysts and their brokerage houses compete. The extant literature mainly uses four proxies for forecast accuracy and/or 
forecast error. Unlike studies based on U.S samples, we do not use absolute forecast error as a dependent variable since our sample includes analyst forecasts made in a variety of currencies. The magnitude of absolute forecasts errors in small currency units (such as Italian lira) would be much higher than those using large currency units. Also, applying exchange rates to convert all of the forecasts into a single currency would introduce noise in our estimates due to exchange rate fluctuations. We use four accuracy variables and follow Clement and Tse (2005) and Malloy (2005) in constructing these variables. These variables are:

Proportional Mean Absolute Forecast Error (pmafe $\mathrm{i}_{\mathrm{it}}$ ): It is defined as the ratio of the difference between the absolute forecast error $\left(\mathrm{AFE}_{\mathrm{ijt}}\right)$ by analyst $\mathrm{i}$ for firm $\mathrm{j}$ at time $\mathrm{t}$ and the mean absolute forecast error $\left(\operatorname{avgAFE} \mathrm{j}_{\mathrm{j}}\right)$ of all of the forecasts for firm $\mathrm{j}$ for fiscal year $\mathrm{T}$ to the mean absolute forecast error $\operatorname{avgAFE}_{\mathrm{jT}}$. From this, it follows that pmafe $\mathrm{ijt}_{\mathrm{ij}}=\left(\mathrm{AFE}_{\mathrm{ijt}}-\operatorname{avgAFE}_{\mathrm{jT}}\right) / \operatorname{avgAFE}_{\mathrm{jT}}$. A positive pmafe $\mathrm{ijt}_{\mathrm{ind}}$ indicates that the absolute forecast error $\mathrm{AFE}_{\mathrm{ijt}}$ by analyst $\mathrm{i}$ for firm $\mathrm{j}$ at time $\mathrm{t}$ is larger than the average absolute forecast error of all of the forecasts for firm $\mathrm{j}$ for the same fiscal year $\mathrm{T}$.

Proportional Mean Price-Scaled Absolute Forecast Error (pmafep $\mathbf{p i j t}_{\mathrm{ijt}}$ : The definition is the same as the definition of pmafe, except that $\mathrm{AFE}_{\mathrm{ijt}}$ is scaled by the latest monthly stock price available from Compustat and is denoted as $\mathrm{AFEP}_{\mathrm{ijt} .}{ }^{7}$ Consequently, pmafep $_{\mathrm{ijt}}=\left(\mathrm{AFEP}_{\mathrm{ijt}}-\operatorname{avgAFEP}_{\mathrm{jT}}\right) / \operatorname{avgAFEP}_{\mathrm{jT}}$.

Demeaned Absolute Price-Scaled Forecast Error $\left(\right.$ dafep $\left._{\mathrm{ijt}}\right)$ : To reduce heteroskedasticity we follow Clement (1999) to demean $\mathrm{AFEP}_{\mathrm{ijt}}$ by the mean price-scaled absolute forecast error for firm $\mathrm{i}$ in the same fiscal year T, i.e., dafep $\mathrm{ijt}_{\mathrm{ijt}}=\mathrm{AFEP}_{\mathrm{ijt}}-\operatorname{avgAFEP}_{\mathrm{jT}}$.

Range (range ${ }_{\mathrm{ijt}}$ ): The ratio of the difference between the highest $\mathrm{AFEP}_{\mathrm{ijt}}$ for firm $\mathrm{j}$, fiscal year $\mathrm{T}$ (denoted $\mathrm{MaxAFEP}_{\mathrm{jT}}$ ) and the $\mathrm{AFEP}_{\mathrm{ijt}}$ considered to the range of $\mathrm{AFEP}_{\mathrm{ijt}}$ for firm $\mathrm{j}$ and fiscal year $\mathrm{T}$, i.e., $\operatorname{range}_{\mathrm{ijt}}=\left(\mathrm{MaxAFEP}_{\mathrm{jT}}-\mathrm{AFEP}_{\mathrm{ijt}}\right) /\left(\mathrm{MaxAFEP}_{\mathrm{jT}}-\operatorname{MinAFEP}_{\mathrm{jT}}\right)$.

\footnotetext{
${ }^{7}$ We obtain similar result when use monthly stock prices from I/B/E/S summary files.
} 
Since the first three dependent variables are forecast error proxies, we multiply each of them by minus one to transform them into forecast accuracy proxies. Consequently, an increase in our dependent variables means that the forecast becomes more precise. Table 2 provides definitions of all the variables used in the paper.

Table 3 provides mean and median values of the accuracy measures. We focus on the first row. The value of pmafep for pure local analysts is obtained as follows. The sample average absolute forecast error (avgAFEP) is 0.0232016 . The average absolute forecast error for pure local analysts is 0.02267 . The value of pmafep of 0.023 is equal to the difference in average absolute forecast error of pure local analysts and the sample average as a fraction of the sample average, $(0.0232016-0.02267) / 0.0232016$. The difference in forecast accuracy between pure local and foreign analysts expressed as percentage of the sample average absolute forecast error is equal to $6.5 \%$ (corresponding to $0.023-(-0.042)$ in the Table), while the difference in forecast accuracy between expatriate analysts and foreign analysts is $8.7 \%$. Table 3 shows that, whether we use means or medians, there is never a significant difference in accuracy between pure local analysts and expatriates. For the first three accuracy measures, the pure local and the expatriate analysts are more accurate than foreign analysts. For the last accuracy measure, however, there is no significant difference between local analysts and foreign analysts whether we use means or medians.

The results of Table 3 suggest that local analysts generally have an advantage over foreign analysts. One should be careful, however, in interpreting Table 3 because it does not control for forecast horizon and it is well-known that forecast horizon is an important determinant of accuracy (see, for instance, Clement, 1999). Further, stale forecasts could lead to large forecast errors that would not be instructive for our study. In the following, we eliminate the worst $1 \%$ forecast errors to ameliorate this problem. While none of our main conclusions is affected by this procedure, some subsidiary results are because our estimates are less precise when we include all observations.

We also report data on the experience of analysts with a firm. We measure firm-specific experience as the number of years between the first forecast on the firm by the analyst and the forecast considered in the analysis. We find that local analysts have more firm-specific experience. On average, local analysts 
have followed a firm almost half a year longer than foreign analysts. This is not surprising in an era of financial globalization, since we would expect more attention to be devoted to firms by foreigners over time. However, this raises the question of whether the local analyst advantage is simply due to a difference in experience. While local analysts are more experienced compared to foreign analysts for local firms, foreign analysts have as much experience as local analysts in the analyst profession. We compute the number of years from the first $\mathrm{I} / \mathrm{B} / \mathrm{E} / \mathrm{S}$ forecast of an analyst (for any firm, whether in our sample or not) to the current forecast and find that there is no economically significant difference between domestic and foreign analysts. Finally, we measure the forecast horizon. It could be that local analysts have an advantage simply because the forecast we consider is closer to the earnings announcement date. We therefore measure the time period between the forecast and the earnings report date on $\mathrm{I} / \mathrm{B} / \mathrm{E} / \mathrm{S}$. We find that there is no significant difference in forecast horizon between local and foreign analysts.

Information asymmetry varies with firm size. We report mean and median market capitalizations of the firms followed by the three groups of analysts. On average, local analysts do not follow larger or smaller firms, but their median firm size is significantly smaller. To the extent that one would expect forecast precision to increase with firm size (Ang and Ciccone, 2001, confirm this relation across countries), it follows that the firm size difference, if not controlled for, could lead to the spurious result that foreign analysts have an advantage over local analysts. Another reason that foreigners might have an advantage is that they come from much larger organizations. The median number of analysts for the brokerage firm of a pure local analyst is 37 , while it is 124 for the brokerage firm of a foreign analyst. However, local analysts benefit from being more specialized. A typical local analyst follows one country, his own. In contrast, a typical foreign analyst follows firms in three countries. Foreign analysts also follow more industries than local analysts. However, foreign analysts are not at a complete disadvantage. They cover fewer firms than local analysts, but produce more forecasts per firm. 


\section{Can the analyst local advantage be explained by analyst or firm characteristics?}

We saw in the previous section that local analysts differ from foreign analysts in a number of ways that are likely to affect the precision of their forecasts. Further, local analysts provide forecasts for smaller firms, which would affect their performance adversely compared to foreign analysts. To evaluate whether local analysts have an advantage, it is important to control for analyst and firm characteristics. After all, it could be that local analysts offer more precise forecasts because they are more specialized and not because they are local.

In Table 4, we report estimates of multiple regressions. The regression t-statistics take into account the firm-level clustering. We also demean all our independent variables by the firm/year averages to reduce heteroskedasticity. In the first regression, we regress the accuracy measure, the proportional mean price-scaled absolute forecast error multiplied by -1 , on the number of analysts from the analyst's brokerage firm, on the forecast horizon, and on the number of industries the analyst covers. We expect precision to be higher if an analyst comes from a larger firm, to be lower if the forecast horizon is longer, and to be lower if he covers more industries. The only variable that is significant is the horizon. We find that a longer horizon reduces the accuracy substantially.

In regression (2), we add a dummy variable for local analysts. This dummy variable is highly significant. In the next regression, we add variables for the firm-specific experience of the analyst and career experience. Consistent with Jacob et al. (1999), Hong et al. (2000), and Bolliger (2004), there is no general learning effect after we control for firm-specific experience. While analysts with more firmspecific experience are more accurate, analysts with more career experience are less accurate. It could be that an analyst with more general experience covers more firms and devotes less resources to each firm he analyzes. Controlling for these analyst characteristics does not affect our estimate of the local analyst advantage. Note that our independent variables are demeaned by firm/year averages. Thus, when fixing independent variables other than the local dummy at their mean values (which are zeros), the predicted value of forecast accuracy increases from 0.017 (intercept) for foreign investors to 0.060 (intercept plus the local dummy estimate) for local investors. Even when we control for various determinants of forecast 
accuracy, the average forecast accuracy of local analysts therefore exceeds the average forecast accuracy of foreign analysts by $5.3 \%$ of the average absolute forecast error. Finally, in regression (4) we consider separately the advantage of pure local analysts and expatriate analysts. There is no difference in the estimate of the advantage for these two types of analysts. Consequently, in the following we focus only on local analysts and do not make a distinction between pure local and expatriate analysts.

In Table 5, we estimate regression (4) of Table 4 on subsamples. First, we split the sample between forecasts made after the fiscal year end and those made before. This is an important distinction in that access to insiders would make the largest difference in precision for forecasts made after the fiscal year end. After the fiscal year end, insiders will have a very good sense of how the numbers will look like. If they tip off their favorite analysts, these analysts should have a substantial advantage in precision. We find that there is a local advantage for both subsamples. However, the point estimate of the local advantage is higher (but not significantly so) for forecasts made after the year end. Table 5 also distinguishes between forecasts made in separate years. We find that the local advantage is significant in 2001 at the $5 \%$ level and in 2003 at the $10 \%$ level, but only marginally so in 2002 (the p-value is 0.103 ).

The second panel of Table 5 reports estimates of the local advantage per country. There is substantial variation in the number of observations across countries, so that it is not surprising that the precision of the estimates varies across countries. Nevertheless, the estimate for the local advantage is positive in all countries but six. There is no country where the local advantage is significantly negative, but the local advantage is significantly positive in ten countries at the $10 \%$ level or better. We discussed in the introduction the work of Bacman and Bolliger (2001). They have two countries where the local advantage (using our language) is significantly negative, Mexico and Columbia. Only Mexico is in our sample. Strikingly, Mexico is the country in our sample where the local advantage is the lowest - it is negative with a t-statistic of -1.58. It follows that their results are similar to those of our paper.

We have established that the local advantage is robust to controlling for various analyst characteristic variables. We now investigate whether the size of the analyst local advantage depends on the information environment of the firm. In other words, are local analysts better for firms where information 
asymmetries are greater? If this were the case, then an important component of the local advantage would be the ability of local analysts to obtain information that is not readily available to analysts outside the country.

We use three different proxies for the firm's information environment. The first regression in Table 6 uses the Transparency and Disclosure score (TD score) of firms as a measure of the information environment. Firms with a higher score release more information. We would therefore expect the local advantage to fall with the TD score. We construct a dummy variable that takes value 1 if the TD score of the firm is above the median score of our sample firms and then create an interaction variable with the dummy for local analysts. A significant negative coefficient on the interaction dummy means that an increase in the transparency level is associated with a lower local advantage. We find that the transparency itself does not affect the precision of forecasts. However, it does affect the local advantage significantly. The local advantage of the more transparent firms is lower by 0.038 than the local advantage of the other firms, so that the local analyst advantage roughly drops in half when one moves from a less transparent firm to a more transparent firm. In the next regression, we use a dummy variable for firms with market capitalization above the median market capitalization in our sample. Though analyst precision is higher for larger firms, firm size does not affect the local advantage at all.

The last regression in Table 6 contrasts the local advantage for purely domestic firms and for firms which are cross-listed in the U.S. Firms cross-listed in the U.S. have a more transparent information environment. ${ }^{8}$ They are also subject to many U.S. laws and regulations that protect investors. ${ }^{9}$ Lang, Lins, and Miller (2003) document that cross-listings are associated with an increase in analyst forecast precision. We confirm their result in our sample. In addition, however, we find that a cross-listing sharply reduces the local advantage. The local advantage of a purely domestic firm is 0.062 , but that advantage drops to 0.026 for firms that are cross-listed in the U.S. Nevertheless, the local advantage is still significant for cross-listed firms.

\footnotetext{
${ }^{8}$ Bailey, Karolyi, and Salva (2005) investigate the impact of cross-listings on the informational environment of firms.

${ }^{9}$ See Doidge, Karolyi, and Stulz (2004).
} 


\section{Do country characteristics help explain the analyst local advantage?}

There is a robust local advantage. This advantage is strongly related to the firms' information environment. The information environment differs across countries. One would therefore expect the local advantage to differ across countries. There are other reasons for the information advantage to differ across countries, however. In Table 7, we explore the relation between the local advantage and a large number of country characteristics which we would expect a priori to influence the local advantage. All the regressions in that Table have the control variables from Table 5, but we do not report the estimates for the coefficients on these variables. We focus on the interaction of the local analyst dummy variable with the country characteristic we are interested in. A significant positive coefficient on the interaction means that an increase in the country characteristics is associated with a higher local advantage. In all regressions, we construct a dummy variable that takes a value of 1 if the value of the country characteristic variable (other than binary variables) is above the median value of our sample countries and then interact that variable with the local analyst dummy.

In the first regression, we investigate the language barrier. Foreign analysts are likely to be fluent in English. We would expect them to be more at a disadvantage for firms in countries where English is not the main language. We use the CIA World Factbook to identify countries where English is the official language. The local advantage is weaker in countries where English is the official language. While the coefficient on the interacted variable is negative, it is insignificant.

We then turn to measures of economic and financial development. The first measure is GDP per capita. It plays no role in the local advantage. Next, we divide the countries into developed and developing countries. There is no evidence that the local advantage differs between the two types of countries. The development of the equity market does not affect the local advantage significantly. We would expect financial markets to be less developed if state ownership in the financial sector is more important. We use a dummy variable that takes value 1 if state ownership of banks in a country is higher than for the median, using the data from Barth, Caprio, and Levine (2003). The interaction has a positive sign, but it is only marginally significant. Finally, we use a measure of openness of the financial sector. 
From the same data source, we construct a variable that takes value equal to 1 if foreign ownership of banks exceeds the median. Again, this variable does not help explain the local advantage. While none of our economic and financial development variables are statistically significant, some of the coefficients imply that greater economic and financial development might be associated with an economically significant reduction in the local advantage.

Dahlquist, Pinkowitz, Stulz, and Williamson (2003) point out portfolio investors can only hold the shares not held by corporate insiders. Consequently, foreign investors have a lower demand for analyst services for stocks in countries where insiders have a larger proportional stake. We use next a dummy variable that takes value 1 if the average ownership of the three largest shareholders for the 10 largest non-financial domestic private firms in a country is above the median of the sample countries using the data from La Porta, Lopez-de-Silanes, and Shleifer (1998). The interaction with this dummy variable is significant and has a positive coefficient as expected.

The supply of analyst services should increase with the importance of institutional investors in an economy since these services are primarily directed towards institutional investors. We find that the precision of analyst forecasts is significantly higher in countries where assets in so-called pooled investment schemes to GDP (as measured by Beck, Demirguc-Kunt, and Levine (1999)) exceed the median in our sample. At the same time, the local advantage is significantly lower in these countries.

Regressions (9) through (14) control for proxies for investor rights, respect for property rights, and enforcement. There is no clear prediction for whether protection of investor rights and of property rights increases the local advantage or reduces it. While poor investor protection is expected to increase the local advantage through several channels, there are also channels through which it could reduce it. With poor protection of property rights, transparency and good governance can be costly for firms (see Stulz, 2005). One would expect local analysts to have an advantage when firms are less transparent. Further, poor protection of property rights affects foreign investors typically more because they are often easier to expropriate, so that their holdings are smaller. With poor investor protection, an important determinant of reported earnings is the extent to which insiders can affect reported earnings adversely by expropriating 
minority shareholders and other investors. One would expect local analysts to have an advantage in ferreting out tunneling by being on the spot. However, at the same time, it is also possible that local analysts are less independent than foreign analysts in countries where protection of investor rights is weak, in which case foreign analysts might provide more accurate forecasts than local analysts.

Our first proxy for investor protection is the legal origin variable from La Porta, Lopez-de-Silanes, Shleifer, and Vishny (LLSV, 1998). Using a dummy variable that takes value 0 for common law countries and 1 for other countries, we find that there is no relation between legal origin and the local advantage in that the interaction between the local dummy and the legal origin dummy is insignificant. The next regression uses the anti-director index of LLSV. The coefficient on the interaction is not significant and its economic significance is trivial. In regression (11), we use a dummy variable that takes value 1 if the index of the respect for property rights from LLSV is above the median in our sample. Again, the interaction is not significant. La Porta, Lopez-de-Silanes, and Shleifer (2005) use an index of public enforcement. We construct a dummy variable that gives a value of 1 to the countries that have an abovemedian value of this index. The interaction with that dummy variable is not significant. It is worth noting, however, that the economic significance of the interactions with the property and public enforcement dummy variables is substantial since the interaction seems to cut the local advantage in half. The final proxy for investor rights is a dummy variable that takes value 1 if class actions are available in a prospectus liability case. We use the data from La Porta, Lopez-de-Silanes, and Shleifer (2005). The interaction is significant and negative. The magnitude of the estimate on the interaction term is also economically large enough to cut the local advantage by more than $70 \%$. Regression (14) uses the measure of enforcement of insider trading laws of Bushman, Piotroski and Smith (2005). We find that the enforcement of insider trading laws is not related to analyst precision or to the analyst local advantage.

We then turn to variables that measure the quality and extent of disclosures. We expect local analysts to have more of an advantage in countries where the quality and extent of disclosures are poorer because they benefit more from informal sources of information acquisition. Our first measure of the quality of disclosures is a proxy for earnings management. This proxy is a dummy variable equal to 1 if the index of 
earnings management of a country from Leuz, Nanda, and Wysocki (2003) is above the median of the countries in our sample. We find that the local advantage is sharply higher in countries with more earnings management. The local advantage is not significant in countries with below-median earnings management. We use next a dummy variable equal to 1 if a country's index of financial disclosures from the Center for International Financial Analysis and Research (CIFAR) is above the median for our sample. We use the data from Bushman, Piotroski, and Smith (2005). We find that the local advantage is significantly weaker in countries with higher disclosure according to that index. Note also that analysts forecasts are generally more (less) accurate in countries with a higher (lower) disclosure level.

Finally, we use a measure of functional efficiency of the capital markets, the $\mathrm{R}^{2}$ measure introduced by Morck, Yeung, and $\mathrm{Yu}(2000)$. This measure is the average $\mathrm{R}^{2}$ of market model regressions for a country. If the market return explains much of the return of individual securities, it means that idiosyncratic information about firms does not get incorporated into stocks well - or, alternatively, that idiosyncratic information is not important. A high $\mathrm{R}^{2}$ means that country specific information is more important for stock returns. Residents may have more information about these factors. For instance, Kaufmann, Mehrez, and Schmukler (2003) find that local managers have useful information in predicting future movements in exchange rates. We find that the local advantage is significantly higher in countries with a high $\mathrm{R}^{2}$ and analyst forecasts are less accurate in these countries.

The results in Table 7 show that the local advantage is less in countries where firms disclose more, manipulate earnings less, the stock market is more functionally efficient, and institutional investors are more active. However, measures of financial development and measures of investor protection do not seem to have a significant association with the size of the local advantage.

\section{Foreign investors and the local analyst advantage}

It would make little sense for foreign analysts to follow firms in a country if foreign investors cannot invest in these firms. One would therefore expect greater supply of analyst services by foreign firms when foreign investors are more interested in a country and hold more equity from that country. If analysts 
become more accurate when the demand for their services increases, perhaps because they command more resources, we would expect the local advantage to fall as the portfolio share of foreign investors in a country increases. At the same time, however, if information asymmetry between local and foreign investors is a determinant of the home bias, we would expect it to increase the analyst local advantage as well. In this case, the information asymmetry would contribute both to the home bias and to the analyst local advantage.

We use four proxies for foreign interest using data for U.S. investors. The first two proxies use data for both equity and debt, while the other two use only equity data. The first variable is a dummy variable that takes value 1 if U.S. holdings of equity and debt scaled by local market GDP are above the median of the countries in our sample. We use the TIC data from the U.S. Treasury. We find that this variable is extremely significant, as shown in regression (1) of Table 8. Essentially, there is little local advantage left for countries where the dummy variable takes a value of 1 . Interestingly, analyst forecasts in general are more precise in countries with greater holdings by U.S. investors. This could be evidence that markets in which U.S. investors invest more are more functionally efficient. We also construct a dummy variable that takes value 1 if equity and debt flows scaled by GDP are above the median for a country. Again, the local advantage is significantly lower for countries where this dummy variable takes value 1 (regression (2) of Table 8). It follows that there is strong evidence that the analyst local advantage is strongest in countries that draw the least interest from U.S. investors.

We now turn to the two proxies that use equity data. The first proxy, used in regression (3), is the fraction of the equity market capitalization of a country held by U.S. investors. We find that the accuracy of analyst forecasts generally increases as U.S. investors have a greater presence in a market. Further, the analyst local advantage is negatively related to the presence of U.S. investors in the market. The second proxy, used in regression (4), is the share of a country's equities in the portfolio of U.S. investors. We find that the accuracy of analysts is not related to that proxy, but the analyst local advantage falls as a country's shares become more important in the portfolio of U.S. investors. 
A possible issue with our results is that U.S. investors might invest more in more transparent firms since there is some evidence in the literature that US investors invest more in better governed firms (see, for instance, Leuz, Lins, and Warnock, 2005). In this case, controlling directly for governance proxies would eliminate the effect we uncover. In unreported tests, we include interaction variables with both U.S. holdings and firm-level transparency variable (TD scores) in the explanatory variables. We find that the relation between U.S. holdings and the local advantage is robust to allowing for a relation between the TD score and the local advantage.

So far, we have shown that the greater the U.S. investor participation in a country, the lower the analyst local advantage. To try to understand better whether the analyst local advantage causes the home bias or vice versa, we use the following identification strategy. If the home bias causes the analyst local advantage, then any increase in the investments of U.S. investors in a country should be associated with a lower analyst local advantage irrespective of why this increase takes place. We can therefore decompose the ownership of shares of U.S. investors in a country into two components, one which is related to the home bias and one which is not. Absent the home bias, U.S. investors would hold the world market float portfolio. ${ }^{10}$ The portfolio they hold is the world market float portfolio minus the home bias component, which we define as the difference between a country's share in the world market float portfolio and the country's share in the portfolio of U.S. investors (the DIFF variable in the regression). Keeping the home bias component constant, an increase in a country's share in the world market portfolio (the WORLD RATIO variable) increases the demand for analyst services by foreign investors and hence should decrease the analyst local advantage if the causation running from the U.S. investor holdings to analyst local advantage is important. Regression (5) shows a regression where the interaction variable is a country's share in the world market float portfolio. We find that neither analyst precision nor the analyst local advantage is related to that variable. Regression (6) uses the DIFF variable as the interaction variable instead. In this case, the analyst precision is negatively related to DIFF. Further, the analyst local advantage is significantly higher when DIFF is higher (that is, when the home bias is higher). If the

\footnotetext{
${ }^{10}$ See Dahlquist, Pinkowitz, Stulz, and Williamson (2003).
} 
analyst local advantage is driven by the demand for analyst services by foreign investors, we should find that DIFF and WORLD RATIO have identical coefficients. This is not the case. To investigate this directly, we estimate a regression where we include both the WORLD RATIO and DIFF. Strikingly, the coefficient on DIFF is much larger in absolute value than the coefficient on WORLD RATIO in the interactions. Equality of the absolute values of the coefficients is rejected with a p-value of 0.0064 . Further, only the interaction with DIFF is significant. All of these results are consistent with causation from information asymmetry between local and foreign residents to the home bias and the analyst local advantage, but not with causation from the home bias to the analyst local advantage.

Our interpretation of the results implies that holdings by U.S. investors in a country should be negatively related to the size of the analyst local advantage. We find that this is the case. When we regress the portfolio share of a country for U.S. investors on the country's share in the world float market portfolio in 2002 and on our estimates of the analyst local advantage estimated for each country in Table 5, we obtain the following results ( $\mathrm{p}$-values in parentheses):

U.S. portfolio share $=0.333+0.967 *$ World float market portfolio share $-2.240 *$ Analyst local advantage

$$
(0.287)(0.000)
$$

The adjusted R-square of the regression is 0.935 . The coefficient on analyst local advantage is significant and negative as expected. We also estimated the regression omitting the U.K. and Japan. Our conclusions are unchanged.

\section{Robustness tests}

We now investigate further the extent to which our estimate of the local advantage is reliable. As discussed in Section 3, we have four measures of accuracy. Except in Table 3, we used only one of these measures. Table 9 estimates regression (3) of Table 4 for each of the three accuracy measures we estimated but have not used so far in our regressions. Because the scale of the measures differs, we would 
expect the local advantage estimate to depend on the accuracy measure used. However, we see that the local advantage is significant irrespective of the measure we use.

As explained in Section 3, we restrict our analysis to firms that are followed by both local and foreign analysts. To evaluate how our estimate of the local advantage is affected by that restriction, we extend our sample to include firms that are followed by only one type of analysts. Again, the significance of our result is not affected. The regressions reported so far use the latest forecast of each analyst. Regression (5) extends the sample to include all analyst forecasts during our sample period. We see that the local advantage remains significant when we add these additional forecasts.

Finally, in regression (6), we add additional control variables that might be related to accuracy. We include counts for the number of forecasts made, the number of firms covered, and the number of countries covered by each analyst. Adding these variables does not affect our results and does not add to the explanatory power of our regressions.

\section{Conclusion}

In this paper, we show that there is a significant analyst local advantage in a sample of 32 countries. This analyst local advantage holds when we control for analyst characteristics as well as firm characteristics. However, it varies substantially across countries. The analyst local advantage is strong in countries where disclosures are weaker, where institutional investors are less important, and where corporate ownership is more concentrated. It is also strong in countries that are underweighted in U.S. portfolios, so that the underlying information asymmetries that lead to the analyst local advantage also contribute to the home bias. 


\section{References}

Ang, James S., and Stephen J. Ciccone, 2001, International differences in analyst forecast properties, Working paper, University of New Hampshire.

Bacmann, Jean-Francois, and Guido Bolliger, 2001, Who are the best? Local versus foreign analysts on the Latin American stock markets, Working paper, University of Neuchâtel, Neuchâtel, Switzerland.

Bailey, Warren, G. Andrew Karolyi, and Carolina Salva, 2005, The economic consequences of increased disclosure: Evidence from international cross-listings, Journal of Financial Economics, forthcoming.

Barth, James, Gerard Caprio, and Ross Levine, 2003, Bank regulation and supervision: What works best? Journal of Financial Intermediation, forthcoming.

Beck, Thorsten, Asli Demirguc-Kunt, and Ross. Levine, 1999, A New Database on Financial Development and Structure, Working paper, World Bank, Washington, D.C.

Bolliger, Guido, 2004, The characteristics of individual analysts' forecasts in Europe, Journal of Banking and Finance 28, 2283-2309.

Brennan, Michael J., and H. Henry Cao, 1997, International portfolio investment flows, Journal of Finance 52, 1851-1880.

Bushman, Robert M., Joseph D. Piotroski and Abbie J. Smith, 2005, Insider trading restrictions and analysts' incentives to follow firms, Journal of Finance 60, 35-66.

Chang, Charles, 2003, Information footholds: expatriate analysts in an emerging market, Working paper, Haas School of Business, U. C. Berkeley.

Chang, James J., Tarun Khanna, and Krishna Palepu, 2000, Analyst activity around the world, Harvard Business School strategy working paper series.

Choe, Hyuk, Bong-Chan Kho and Rene Stulz, 2005, Do domestic investors have an edge? The trading experience of foreign investors in Korea, Review of Financial Studies 18, 795-829.

Clement, Michael B., 1999, Analyst forecast accuracy: Do ability, resources, and portfolio complexity matter?, Journal of Accounting and Economics 27, 285-303.

Clement, Michael B., and Senyo Y. Tse, 2005, Financial analyst characteristics and herding behavior in forecasting, Journal of Finance 60, (1): 307-341.

Conroy, Robert M., Yujiro Fukuda and Robert S. Harris, 1997, Securities houses and earnings forecasts in Japan: What makes for an accurate prediction?, Financial Analysts Journal 53, (4): 29-40.

Coval, Joshua D., and Tobias J. Moskowitz, 1999, Home bias at home: Local equity preference in domestic portfolios, Journal of Finance 54, 2045-2073. 
Coval, Joshua D., and Tobias J. Moskowitz, 2001, The geography of investment: Informed trading and asset prices, Journal of Political Economy 4, 811-841.

Dahlquist, Magnus, Lee Pinkowitz, René M. Stulz, and Rohan Williamson, 2003, Corporate governance and the home bias, Journal of Financial and Quantitative Analysis 38, 87-110.

Doidge, Craig, G. Andrew Karolyi, and René M. Stulz, 2004, Why do countries matter so much for corporate governance?, ECGI working paper series in finance, ECGI.

Dvorak, Tomas, 2005, Do domestic investors have an information advantage? Evidence from Indonesia, Journal of Finance 60, 817-839.

Durnev, Art, and E. Han Kim, 2004, To steal or not to steal: firm attributes, legal environment, and valuation, Journal of Finance, forthcoming.

Froot, Kenneth K., Paul. O'Connell, and Mark Seasholes, 2001, The portfolio flows of international investors, Journal of Financial Economics 59, 151-193.

Froot, Kenneth K., and Tarun Ramadorai, 2001, The information content of international portfolio flows, unpublished working paper, Harvard Business School, Cambridge, MA.

Gehrig, Thomas., 1993, An information based explanation of the domestic bias in international equity investment, Scandinavian Journal of Economics 95, 97-109.

Grinblatt, Mark, and Matti Keloharju, 2000, The investment behavior and performance of various investor types: A study of Finland's unique data set, Journal of Financial Economics 55, 43-67.

Hau, Harald, 2001, Location matters: An examination of trading profits, Journal of Finance 56, 19591983.

Healy, Paul M., and Krishna G. Palepu, 2001, Information asymmetry, corporate disclosure, and the capital markets: A review of the empirical disclosure literature, Journal of Accounting and Economics 31, 405-440.

Hong, Harrison, Jeffrey D. Kubik, and Jeremy C. Stein, 2004, Thy neighbor's portfolio: word-of-mouth effects in the holdings and trades of money managers, Journal of Finance, forthcoming.

Hope, Ole-Kristian, 2003, Disclosure practices, enforcement of accounting standards, and analysts' forecast accuracy: An international study, Journal of Accounting Research 41, (2), 235-272.

Huberman, Gur, 2001, Familiarity breeds investment, Review of Financial Studies 14, 659-680.

Ivkovic, Zoran and Scott Weisbenner, 2005, Local does as local is: information content of the geography of individual investors common stock investments, Journal of Finance 60, 267-306.

Jacob, John, Thomas. Lys, and Margaret Neale, 1999, Expertise in forecasting performance of security analysts, Journal of accounting Economics 28, 51-82. 
Kang, Jun-Koo. and René M. Stulz, 1997, Why is there a home bias? An analysis of foreign portfolio equity ownership in Japan, Journal of Financial Economics 46, 3-28.

Khanna, Tarun, Krishna G. Palepu, and Suraj Srinivasan, 2004, Disclosure practices of foreign companies interacting with U.S. markets, Journal of Accounting Research 42, 475-508.

Karolyi, G. Andrew, and René M. Stulz, 2003, Are assets priced locally or globally?, in G. Constantinides, M. Harris and R. M. Stulz, eds.: The Handbook of the Economics of Finance, NorthHolland Publishers, New York, NY.

Kaufmann, Daniel, Gil Mehrez, and Sergio L. Schmukler, 2003, Predicting currency fluctuations and crises: Do resident firms have an informational advantage?, World Bank Policy Research Paper No. 2259, World Bank, Washington, D.C.

La Porta, Rafael, Florencio Lopez-de-Silanes, Andrei Shleifer, and Robert W. Vishny, 1998, Law and Finance, Journal of Political Economy 106, 1113-1155.

La Porta, Rafael, Florencio Lopez-de-Silanes, Andrei Shleifer, 2005, What works in Securities laws, Journal of Finance, forthcoming.

Lang, Mark H., Lins, Karl V., and Darius Miller, 2003, ADRs., analysts, and accuracy: Does cross-listing in the U.S. improve a firm's information environment and increase market value?, Journal of Accounting Research 41, 317-346.

Leuz, Christian, Karl V. Linz, and Francis E. Warnock, 2005, Do foreigners invest less in poorly governed firms?, unpublished working paper, Wharton School, University of Pennsylvania, Philadelphia, PA.

Leuz, Christian, Dhananjay Nanda, and Peter D. Wysocki, 2003, Earnings management and investor protection: an international comparison, Journal of Financial Economics 69, 505-527.

Lewis, Karen K, 1999, Trying to explain home bias in equities and consumption, Journal of Economic Literature 37, 571-608.

Malloy, Christopher J., 2005, The Geography of equity analysis, Journal of Finance 60, 719-755.

Morck, Randall, Bernard Yeung and Wayne Yu, 2000, The Information content of stock markets: why do emerging markets have synchronous stock price movements?, Journal of Financial Economics 58, 215260.

Orpurt, Steven, 2004, Local analyst earnings forecast advantages in Europe, Working paper, University of Chicago.

Seasholes, Mark, 2000, Smart foreign traders in emerging markets, Working paper, Harvard University.

Stulz, René M., 2005, The limits of financial globalization, Journal of Finance 60, 1595-1638. 


\section{Table 1 Distribution of sample firms and analysts by country and analyst group}

The table shows the number of firms, pure local, expatriate, and foreign analysts in each country. The sample firms are the intersection of I/B/E/S for non-U.S. firms, Nelson's Directories of Investment Research, and Standard and Poor's Transparency and Disclosure. The final sample contains 1,020 pure local, 1,563 expatriate, and 1,920 foreign analysts covering 611 firms from 32 countries over the period of 2001 to 2003. Local analysts are analysts located in the same country as their covered firms, while foreign analysts are located in a different country from the firms they cover. Local analysts are furthered classified into pure local and expatriate analysts. Pure local analysts work for local research firms, while expatriate analysts work for research firms from foreign countries. The number of analysts across countries does not add up to the total number since an analyst (particularly a foreign analyst) can analyze several firms in different countries. Similarly, the number of local and foreign analysts does not add up to the total number of distinct analysts since an analyst can switch her brokerage firm across borders.

\begin{tabular}{|c|c|c|c|c|c|c|}
\hline \multirow{3}{*}{ Country } & \multirow{3}{*}{ No. of firms } & \multicolumn{4}{|c|}{ Number of analysts } & \multirow{3}{*}{$\mathrm{A} / \mathrm{C}$} \\
\hline & & \multirow{2}{*}{ Foreign (A) } & \multicolumn{2}{|c|}{ Local analysts (B) } & \multirow{2}{*}{$\begin{array}{c}\text { Total number of } \\
\text { distinct analyst }(\mathrm{C})\end{array}$} & \\
\hline & & & Pure local & Expatriate & & \\
\hline Argentina & 7 & 25 & 2 & 2 & 29 & 0.86 \\
\hline Australia & 16 & 27 & 20 & 77 & 123 & 0.22 \\
\hline Austria & 2 & 24 & 2 & 1 & 27 & 0.89 \\
\hline Belgium & 6 & 70 & 13 & 9 & 92 & 0.76 \\
\hline Brazil & 23 & 85 & 16 & 27 & 126 & 0.66 \\
\hline Chile & 7 & 25 & 1 & 3 & 29 & 0.86 \\
\hline China & 9 & 67 & 0 & 7 & 74 & 0.91 \\
\hline Denmark & 6 & 99 & 7 & 26 & 132 & 0.75 \\
\hline Finland & 4 & 80 & 10 & 10 & 100 & 0.80 \\
\hline France & 47 & 526 & 153 & 130 & 806 & 0.65 \\
\hline Germany & 31 & 454 & 94 & 64 & 611 & 0.74 \\
\hline Hong Kong & 17 & 26 & 37 & 141 & 202 & 0.13 \\
\hline India & 17 & 25 & 10 & 53 & 86 & 0.29 \\
\hline Indonesia & 11 & 23 & 0 & 19 & 42 & 0.55 \\
\hline Ireland & 3 & 43 & 8 & 1 & 51 & 0.84 \\
\hline Italy & 26 & 250 & 32 & 56 & 335 & 0.75 \\
\hline Japan & 61 & 18 & 25 & 108 & 146 & 0.12 \\
\hline Korea & 13 & 13 & 7 & 27 & 47 & 0.28 \\
\hline
\end{tabular}




\begin{tabular}{|c|c|c|c|c|c|c|}
\hline Malaysia & 23 & 63 & 27 & 53 & 140 & 0.45 \\
\hline Mexico & 14 & 72 & 7 & 11 & 90 & 0.80 \\
\hline Netherlands & 23 & 405 & 69 & 32 & 503 & 0.80 \\
\hline Norway & 4 & 32 & 5 & 23 & 60 & 0.53 \\
\hline Philippines & 8 & 34 & 0 & 26 & 60 & 0.57 \\
\hline Portugal & 7 & 87 & 16 & 2 & 105 & 0.83 \\
\hline Singapore & 9 & 40 & 28 & 55 & 123 & 0.33 \\
\hline South Africa & 3 & 11 & 1 & 16 & 28 & 0.39 \\
\hline Spain & 17 & 208 & 8 & 56 & 271 & 0.77 \\
\hline Sweden & 18 & 217 & 47 & 39 & 298 & 0.73 \\
\hline Switzerland & 17 & 300 & 61 & 11 & 372 & 0.81 \\
\hline Taiwan & 25 & 48 & 4 & 62 & 113 & 0.42 \\
\hline Thailand & 19 & 41 & 5 & 33 & 77 & 0.53 \\
\hline The U.K. & 118 & 291 & 305 & 385 & 950 & 0.30 \\
\hline Total & 611 & 1,920 & 1,020 & 1,563 & 3,482 & \\
\hline
\end{tabular}




\section{Table 2 Description of variables}

The table describes the variable definitions.

\section{A. Dependent variables}

\begin{tabular}{|c|c|}
\hline pmafe $_{i j t}$ & 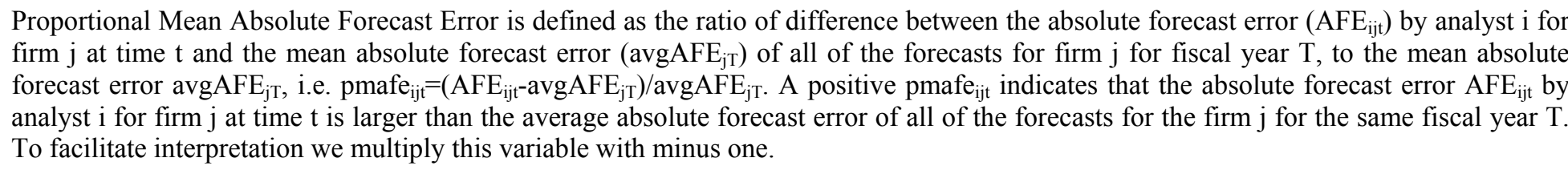 \\
\hline pmafep $_{\mathrm{ijt}}$ & $\begin{array}{l}\text { Proportional Mean Price-scaled Absolute Forecast Error is defined similarly as pmafe, except that } A_{F} E_{i j t} \text { is scaled by the latest available } \\
\text { monthly stock price from Compustat, i.e. pmafep } p_{\mathrm{ijt}}=\left(\mathrm{AFEP}_{\mathrm{ijt}}-\operatorname{avgAFEP}_{\mathrm{jT}}\right) / \mathrm{avgAFEP}_{\mathrm{jT}} \text {. To facilitate interpretation we multiply this variable } \\
\text { with minus one. }\end{array}$ \\
\hline dafep $_{\mathrm{ijt}}$ & $\begin{array}{l}\text { Demeaned Absolute Forecast Errors scaled by the most recent stock prices in the previous fiscal year. The price-scaled absolute forecast } \\
\text { error AFEP } \mathrm{ijt}_{\mathrm{j}} \text { of analyst } \mathrm{i} \text { for firm } \mathrm{j} \text { at time } \mathrm{t} \text { is computed as the price-scaled absolute difference between an earnings forecast and the } \\
\text { actually disclosed earnings. To reduce heteroskedasticity we follow Clement (1999) to demean AFEP } \text { Pijt }_{\text {by }} \text { by mean price-scaled absolute } \\
\text { forecast error for firm } \mathrm{j} \text { in the same fiscal year. To facilitate interpretation we multiply this variable with minus one. }\end{array}$ \\
\hline range $_{i j t}$ & $\begin{array}{l}\text { range }_{\mathrm{ijt}} \text { is the ratio of the difference between the maximum afep } \mathrm{ijt}_{\mathrm{jt}} \text { for firm } \mathrm{j} \text {, fiscal year } \mathrm{T} \text { and a particular afep } \mathrm{p}_{\mathrm{ijt}} \text {, to the range of afep } \mathrm{ijt}_{\mathrm{ijt}} \text { for } \\
\text { firm } \mathrm{j} \text { and fiscal year } \mathrm{T} \text {. }\end{array}$ \\
\hline
\end{tabular}

B. Independent variables (firm- or analyst-level)

\begin{tabular}{l|l}
\hline local $_{\mathrm{ijt}}$ & Dummy variable that equals 1 if analyst $\mathrm{i}$ is located in the same country as the covered firm $\mathrm{j}$ at time $\mathrm{t}$, and 0 otherwise. \\
\hline pure local $\mathrm{ijt}_{\mathrm{f}}$ & $\begin{array}{l}\text { Dummy variable that equals } 1 \text { if analyst } \mathrm{i} \text { is located in the same country as the covered firm } \mathrm{j} \text { at time } \mathrm{t} \text { and work for local research firms, } \\
\text { and } 0 \text { otherwise. }\end{array}$ \\
\hline
\end{tabular}




\begin{tabular}{|c|c|}
\hline expatriate $_{\mathrm{ijt}}$ & $\begin{array}{l}\text { Dummy variable that equals } 1 \text { if analyst } \mathrm{i} \text { is located in the same country as the covered firm } \mathrm{j} \text { at time } \mathrm{t} \text { and work for research firms from } \\
\text { foreign countries, and } 0 \text { otherwise. }\end{array}$ \\
\hline horizon $_{\mathrm{ijt}}$ & $\begin{array}{l}\text { Forecast age in years between the forecast date } t \text { and the corresponding } I / B / E / S \text { report date of the actual earnings. } i \text { denotes analysts and } j \\
\text { denotes firms. }\end{array}$ \\
\hline firmexp $p_{i j t}$ & $\begin{array}{l}\text { Analyst firm specific experience, defined as the time interval in years between analyst } \mathrm{i} \text { 's first forecast for a particular firm } \mathrm{j} \text { and his } \\
\text { forecast at time } \mathrm{t} \text { for firm } \mathrm{j} \text {. }\end{array}$ \\
\hline genexp $_{\text {it }}$ & $\begin{array}{l}\text { Analyst general experience, defined as the time interval in years between analyst i's first forecast in the } \mathrm{I} / \mathrm{B} / \mathrm{E} / \mathrm{S} \text { database and his current } \\
\text { forecast at time } \mathrm{t} \text {. }\end{array}$ \\
\hline $\mathrm{mv}_{\mathrm{jy}}$ & Market capitalization in US million dollars for firm $\mathrm{j}$ in year $\mathrm{Y}$. \\
\hline mvdum $_{\mathrm{jY}-1}$ & $\begin{array}{l}\text { Dummy variable indicating firm size. It is } 1 \text { if the market value of firm } \mathrm{j} \text { is above the median market value of all of the firms from the same } \\
\text { country in year Y-1. }\end{array}$ \\
\hline brsize $_{\mathrm{iY}}$ & Brokerage size, defined as the number of analysts working for the $\mathrm{I} / \mathrm{B} / \mathrm{E} / \mathrm{S}$ brokerage that analyst $\mathrm{i}$ is associated with in year $\mathrm{Y}$. \\
\hline $\operatorname{ind}_{\mathrm{iY}}$ & Number of $\mathrm{I} / \mathrm{B} / \mathrm{E} / \mathrm{S}$ industries analyst i covers in year $\mathrm{Y}$. \\
\hline nctry $_{\mathrm{iY}}$ & Number of countries analyst $\mathrm{i}$ covers in year $\mathrm{Y}$. \\
\hline ntik $_{\mathrm{iY}}$ & Number of firms analyst i covers in year $Y$. \\
\hline nfest $_{\mathrm{iY}}$ & Number of forecasts analyst i provides in year $\mathrm{Y}$ for all of the firms he covers. \\
\hline tdscore $_{j}$ & $\begin{array}{l}\text { Transparency dummy equal to } 1 \text { if the overall score in Standard \& Poor's Transparency and Disclosure dataset for firm } \mathrm{j} \text { is above the } \\
\text { median score for all of the covered firms in the final sample, and } 0 \text { otherwise. }\end{array}$ \\
\hline
\end{tabular}



of New York.

C. Independent variables (country-level)

\begin{tabular}{|c|c|}
\hline English language $_{i}$ & $\begin{array}{l}\text { Dummy variable equal to } 1 \text { if English is an official language for the domicile country of the covered firm, and } 0 \text { otherwise. The original } \\
\text { source is from the CIA World Factbook and the website of http://www.cepii.fr/anglaisgraph/bdd/distances.htm }\end{array}$ \\
\hline GDP per capita ${ }_{i}$ & $\begin{array}{l}\text { Dummy variable equal to } 1 \text { if the GDP of a country is above the median of the countries in the final sample, and } 0 \text { otherwise. The data is } \\
\text { from the World Development Indicator } 2002 \text {. }\end{array}$ \\
\hline developed market $_{\mathrm{i}}$ & Dummy variable equal to 1 if country $i$ is a developed country, and 0 otherwise. \\
\hline equity market ${ }_{i}$ & $\begin{array}{l}\text { Dummy variable equal to } 1 \text { if the index of the equity market importance is above the median of the countries in the final sample, and } 0 \\
\text { otherwise. The raw data are from Leuz, Nanda, and Wysocki (2003). }\end{array}$ \\
\hline state ownership $_{\mathrm{i}}$ & $\begin{array}{l}\text { Dummy variable equal to } 1 \text { if the state ownership of banking for country } i \text { is above the median of the countries in the final sample, and } 0 \\
\text { otherwise. The data are from Barth, Caprio, and Levine (2003). }\end{array}$ \\
\hline $\begin{array}{l}\text { foreign bank } \\
\text { ownership }_{i}\end{array}$ & $\begin{array}{l}\text { Dummy variable equal to } 1 \text { if the foreign ownership of banking for country } i \text { is above the median of the countries in the final sample, and } 0 \\
\text { otherwise. The data are from Barth, Caprio, and Levine (2003). }\end{array}$ \\
\hline $\begin{array}{l}\text { ownership } \\
\text { concentration }_{\mathrm{i}}\end{array}$ & $\begin{array}{l}\text { Dummy variable equal to } 1 \text { if the average ownership of three largest shareholders for the } 10 \text { largest non-financial domestic private firms in } \\
\text { country } \mathrm{i} \text { is above the median of the countries in the final sample, and } 0 \text { otherwise. The data are from La Porta et al. (1998). }\end{array}$ \\
\hline pooled investment $t_{i}$ & $\begin{array}{l}\text { Dummy variable equal to } 1 \text { if the average of total assets of pooled investment schemes to GDP between } 1993 \text { and } 1995 \text { for country i is } \\
\text { above the median of the countries in the final sample, and } 0 \text { otherwise. The data are from Beck, Demirguc-Kunt, and Levine (1999). }\end{array}$ \\
\hline legal origin ${ }_{i}$ & Dummy variable equal to 0 if the legal origin of country $\mathrm{i}$ is common law, and 1 otherwise. The raw data are from La Porta et al. (1998). \\
\hline
\end{tabular}




\begin{tabular}{|c|c|}
\hline antidirector rights $_{i}$ & $\begin{array}{l}\text { Dummy variable equal to } 1 \text { if anti-director index for country } \mathrm{i} \text { is above the median of the countries in the final sample. The raw anti- } \\
\text { director index ranges from } 0 \text { to 5, with higher scores for stronger rights. The raw data are from La Porta et al. (1998). }\end{array}$ \\
\hline property rights $_{\mathrm{i}}$ & $\begin{array}{l}\text { Dummy variable equal to } 1 \text { if the property rights index for country } \mathrm{i} \text { is above the median of the countries in the final sample, and } 0 \\
\text { otherwise. The raw data are from La Porta et al. (1998). }\end{array}$ \\
\hline publ enforcement $t_{i}$ & $\begin{array}{l}\text { Dummy variable equal to } 1 \text { if the index of public enforcement for country } i \text { is above the median of the countries in the final sample, and } 0 \\
\text { otherwise. The index equals the arithmetic mean of: (1) Supervisor characteristics index; (2) Investigative powers index; (3) Orders index; } \\
\text { and (4) Criminal index. The data are from La Porta et al. (2005). }\end{array}$ \\
\hline 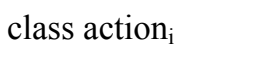 & Dummy variable equal to 1 if class action suits are available in a prospectus liability case. The data are from La Porta et al. (2005). \\
\hline $\begin{array}{l}\text { insider trading }_{\text {enforcement }} \\
\text { enfor }\end{array}$ & $\begin{array}{l}\text { Dummy variable indicating whether a covered firm } \mathrm{j} \text { is from a country with insider trading law enforcement according to the data source } \\
\text { from Bushman, Piotroski and Smith }(2005) \text {. }\end{array}$ \\
\hline $\begin{array}{l}\text { earnings } \\
\text { management }_{\mathrm{i}}\end{array}$ & $\begin{array}{l}\text { Dummy variable equal to } 1 \text { if the index of earnings management for country } i \text { is above the median of the countries in the final sample, and } \\
0 \text { otherwise. The data are from Leuz, Nanda and Wysocki (2003). }\end{array}$ \\
\hline CIFAR $_{i}$ & $\begin{array}{l}\text { Dummy variable equal to } 1 \text { if the index of financial disclosure for country } i \text { is above the median of the countries in the final sample, and } 0 \\
\text { otherwise. The data are from Bushman, Piotroski, and Smith (2004). }\end{array}$ \\
\hline $\mathrm{R}^{2}$ Morck $_{\mathrm{i}}$ & $\begin{array}{l}\text { Dummy variable equal to } 1 \text { if the average of the R2s estimated from the market model for country } i \text { is above the median of the countries in } \\
\text { the final sample, and } 0 \text { otherwise. The data are from Morck, Yeung, and Yu (2000). }\end{array}$ \\
\hline US holdings $_{i}$ & $\begin{array}{l}\text { Dummy variable equal to } 1 \text { if US investors' overseas holding of equity and debt scaled by local market GDP is above the median of the } \\
\text { countries in the final sample, and } 0 \text { otherwise. The data are from the US Treasury Department. }\end{array}$ \\
\hline US flows $_{\mathrm{i}}$ & $\begin{array}{l}\text { Dummy variable equal to } 1 \text { if the US investors' overseas equity and debt flow scaled by local market GDP is above the median of the } \\
\text { countries in the final sample, and } 0 \text { otherwise. The data are from the US Treasury Department. }\end{array}$ \\
\hline
\end{tabular}




\begin{tabular}{l|l}
\hline US equity & The fraction of the local equity market capitalization held by U.S. investors. \\
\hline US portfolio & \\
\hline WORLD RATIO & The share of a country's equities in the portfolio of U.S. investors. \\
\hline DIFF $_{i}$ & The share of a country's market capitalization in the world market portfolio. \\
\hline
\end{tabular}




\section{Table 3 Summary statistics by analysts groups}

The table shows summary statistics of main variables used in the analysis. The sample firms are the intersection of I/B/E/S for non-U.S. firms, Nelson's Directories of Investment Research, and Standard and Poor's Transparency and Disclosure. The final sample contains 1,020 pure local, 1,563 expatriate, and 1,920 foreign analysts covering 611 firms from 32 countries over the period of 2001 to 2003 . Local analysts are analysts located in the same country as the firms they cover, while foreign analysts are located in a different country from the firms they cover. Local analysts are furthered classified into pure local and expatriate analysts. Pure local analysts work for local research firms, while expatriate analysts work for research firms from foreign countries. The summary statistics of forecast-related variables are computed by partitioning each earning forecast (and its related variables) into one of the three different groups depending on the analyst identity. The summary statistics of analyst-related variables are computed as follows. The average value of analyst-related variable is computed for each analyst in each of the three different analyst groups. The mean and median are then computed across analysts for each analyst group. To facilitate interpretation, we multiply the forecast variables by minus one, so that higher values of dependent variable imply more accurate forecasts. All variables are as defined in Table 2. Numbers in parenthesis are p-values.

\begin{tabular}{|c|c|c|c|c|c|c|c|c|c|c|c|c|}
\hline \multirow[b]{2}{*}{ Variable } & \multicolumn{2}{|c|}{ Pure local (A) } & \multicolumn{2}{|c|}{ Expatriate (B) } & \multicolumn{2}{|c|}{ Foreign $(\mathrm{C})$} & \multicolumn{2}{|c|}{ A-B } & \multicolumn{2}{|c|}{ B-C } & \multicolumn{2}{|c|}{ A-C } \\
\hline & Mean & Median & Mean & Median & Mean & Median & $\begin{array}{l}\text { Mean } \\
\text { t-test }\end{array}$ & $\begin{array}{l}\text { Wilcoxon } \\
\text { Median } \\
\text { test }\end{array}$ & $\begin{array}{l}\text { Mean } \\
\text { t-test }\end{array}$ & $\begin{array}{l}\text { Wilcoxon } \\
\text { Median } \\
\text { test }\end{array}$ & $\begin{array}{l}\text { Mean } \\
\text { t-test }\end{array}$ & $\begin{array}{c}\text { Wilcoxon } \\
\text { Median } \\
\text { test }\end{array}$ \\
\hline \multicolumn{13}{|c|}{ Panel A: Forecast-related variables } \\
\hline pmafep & 0.023 & 0.168 & 0.045 & 0.156 & -0.042 & 0.153 & $(0.16)$ & $(0.91)$ & $(0.00)$ & $(0.00)$ & $(0.00)$ & $(0.00)$ \\
\hline pmafe & 0.024 & 0.141 & 0.049 & 0.155 & -0.045 & 0.146 & $(0.10)$ & $(0.64)$ & $(0.00)$ & $(0.00)$ & $(0.00)$ & $(0.01)$ \\
\hline dafep & 0.001 & 0.001 & 0.000 & 0.001 & -0.001 & 0.001 & $(0.68)$ & $(0.22)$ & $(0.01)$ & $(0.36)$ & $(0.01)$ & $(0.04)$ \\
\hline range & 0.638 & 0.736 & 0.634 & 0.728 & 0.639 & 0.735 & $(0.51)$ & $(0.56)$ & $(0.31)$ & $(0.95)$ & $(0.84)$ & $(0.52)$ \\
\hline firmexp & 2.077 & 1.315 & 1.968 & 1.422 & 1.595 & 1.005 & $(0.01)$ & $(0.80)$ & $(0.00)$ & $(0.00)$ & $(0.00)$ & $(0.00)$ \\
\hline genexp & 3.386 & 2.704 & 3.288 & 2.753 & 3.648 & 2.778 & $(0.06)$ & $(0.47)$ & $(0.00)$ & $(0.00)$ & $(0.00)$ & $(0.00)$ \\
\hline horizon & 0.406 & 0.321 & 0.408 & 0.321 & 0.411 & 0.321 & $(0.77)$ & $(0.50)$ & $(0.50)$ & $(0.20)$ & $(0.36)$ & $(0.66)$ \\
\hline No. of obs. & \multicolumn{2}{|c|}{4,412} & \multicolumn{2}{|c|}{6,536} & \multicolumn{2}{|c|}{9,477} & & & & & & \\
\hline
\end{tabular}




\begin{tabular}{|c|c|c|c|c|c|c|c|c|c|c|c|c|}
\hline \multirow[b]{2}{*}{ Variable } & \multicolumn{2}{|c|}{ Pure local (A) } & \multicolumn{2}{|c|}{ Expatriate (B) } & \multicolumn{2}{|c|}{ Foreign $(\mathrm{C})$} & \multicolumn{2}{|c|}{ A-B } & \multicolumn{2}{|c|}{$\mathrm{B}-\mathrm{C}$} & \multicolumn{2}{|c|}{$\mathrm{A}-\mathrm{C}$} \\
\hline & Mean & Median & Mean & Median & Mean & Median & $\begin{array}{c}\text { Mean } \\
\text { t-test }\end{array}$ & $\begin{array}{c}\text { Wilcoxon } \\
\text { Median } \\
\text { test }\end{array}$ & $\begin{array}{c}\text { Mean } \\
\text { t-test }\end{array}$ & $\begin{array}{l}\text { Wilcoxon } \\
\text { Median } \\
\text { test }\end{array}$ & $\begin{array}{c}\text { Mean } \\
\text { t-test }\end{array}$ & $\begin{array}{c}\text { Wilcoxon } \\
\text { Median } \\
\text { test }\end{array}$ \\
\hline \multicolumn{13}{|c|}{ Panel B: Analyst-related variables } \\
\hline $\mathrm{mv}$ & 17,723 & 8,681 & 16,082 & 7,145 & 18,243 & 9,993 & $(0.15)$ & $(0.00)$ & $(0.02)$ & $(0.00)$ & $(0.57)$ & $(0.05)$ \\
\hline brsize & 90.439 & 37.857 & 133.795 & 109.000 & 137.234 & 124.000 & $(0.00)$ & $(0.00)$ & $(0.32)$ & $(0.14)$ & $(0.00)$ & $(0.00)$ \\
\hline ind & 4.028 & 3.000 & 4.022 & 3.000 & 4.377 & 3.750 & $(0.96)$ & $(0.48)$ & $(0.00)$ & $(0.00)$ & $(0.00)$ & $(0.00)$ \\
\hline nctry & 2.020 & 1.000 & 2.241 & 1.683 & 3.225 & 3.000 & $(0.00)$ & $(0.00)$ & $(0.00)$ & $(0.00)$ & $(0.00)$ & $(0.00)$ \\
\hline ntik & 9.784 & 8.250 & 8.995 & 8.000 & 8.375 & 7.528 & $(0.00)$ & $(0.09)$ & $(0.00)$ & $(0.00)$ & $(0.00)$ & $(0.00)$ \\
\hline nfest & 20.913 & 18.000 & 24.541 & 21.688 & 22.823 & 19.000 & $(0.00)$ & $(0.00)$ & $(0.02)$ & $(0.00)$ & $(0.00)$ & $(0.00)$ \\
\hline No. of obs. & \multicolumn{2}{|c|}{1,020} & \multicolumn{2}{|c|}{1,563} & \multicolumn{2}{|c|}{1,920} & & & & & & \\
\hline
\end{tabular}




\section{Table 4 Forecast accuracy and local analyst advantage}

This table presents ordinary least squares regression results of forecast accuracy on local analyst dummy and analyst, forecast and firm characteristics. The dependent variable (Pmafep) is computed as Pmafep $_{\mathrm{ijt}}=\left(\mathrm{AFEP}_{\mathrm{ijt}} \mathrm{t}^{-}\right.$ $\operatorname{avgAFEP} P_{\mathrm{jT}} / \operatorname{avgAFEP} \mathrm{j}_{\mathrm{j}}$ where $\mathrm{AFEP}_{\mathrm{ijt}}$ is the absolute forecast error by analyst $\mathrm{i}$ for firm $\mathrm{j}$ at time $\mathrm{t}$ scaled by the latest available monthly stock price and avgAFEP ${ }_{\mathrm{j} T}$ is the mean absolute forecast error of all of the forecasts for firm $\mathrm{j}$ for fiscal year T. To facilitate interpretation, we multiply this variable by minus one, so that higher values of the dependent variable imply more accurate forecasts. All variables are as defined in Table 2. Independent variables are demeaned by the firm/year averages to reduce heteroskedasticity. T-statistics adjusted for firm-level clustering are in parentheses.

\begin{tabular}{|c|c|c|c|c|}
\hline Variables & (1) & (2) & (3) & (4) \\
\hline $\begin{array}{l}\text { Dummy for } \\
\text { local analysts }\end{array}$ & & $\begin{array}{c}0.046 \\
(4.31)\end{array}$ & $\begin{array}{r}0.043 \\
(3.98)\end{array}$ & \\
\hline $\begin{array}{l}\text { Dummy for } \\
\text { pure local analysts }\end{array}$ & & & & $\begin{array}{r}0.045 \\
(3.00)\end{array}$ \\
\hline $\begin{array}{l}\text { Dummy for } \\
\text { Expatriate analysts }\end{array}$ & & & & $\begin{array}{r}0.041 \\
(3.46)\end{array}$ \\
\hline Broker size & $\begin{array}{c}0.002 \\
(0.36)\end{array}$ & $\begin{array}{c}0.006 \\
(1.00)\end{array}$ & $\begin{array}{r}0.007 \\
(1.23)\end{array}$ & $\begin{array}{r}0.007 \\
(1.27)\end{array}$ \\
\hline Forecast horizon & $\begin{array}{r}-0.571 \\
(-15.58)\end{array}$ & $\begin{array}{r}-0.568 \\
(-15.50)\end{array}$ & $\begin{array}{r}-0.570 \\
(-15.55)\end{array}$ & $\begin{array}{r}-0.570 \\
(-15.57)\end{array}$ \\
\hline $\begin{array}{l}\text { Number of industries } \\
\text { covered }\end{array}$ & $\begin{array}{r}-0.002 \\
(-0.80)\end{array}$ & $\begin{array}{l}-0.000 \\
(-0.24)\end{array}$ & $\begin{array}{r}0.000 \\
(0.05)\end{array}$ & $\begin{array}{r}0.000 \\
(0.05)\end{array}$ \\
\hline $\begin{array}{l}\text { Firm-specific } \\
\text { experience }\end{array}$ & & & $\begin{array}{l}0.008 \\
(2.03)\end{array}$ & $\begin{array}{r}0.008 \\
(2.02)\end{array}$ \\
\hline Career experience & & & $\begin{array}{l}-0.010 \\
(-3.85)\end{array}$ & $\begin{array}{l}-0.010 \\
(-3.85)\end{array}$ \\
\hline Constant & $\begin{array}{r}0.040 \\
(11.43)\end{array}$ & $\begin{array}{r}0.015 \\
(2.36)\end{array}$ & $\begin{array}{r}0.017 \\
(2.67)\end{array}$ & $\begin{array}{r}0.017 \\
(2.66)\end{array}$ \\
\hline No. of obs. & 20,221 & 20,221 & 20,221 & 20,221 \\
\hline Adjusted $\mathrm{R}^{2}$ & 0.041 & 0.042 & 0.043 & 0.043 \\
\hline $\begin{array}{l}\text { Test: pure local=expat } \\
\text { F-statistic } \\
\text { (p-value) }\end{array}$ & & & & $\begin{array}{l}0.08 \\
0.78\end{array}$ \\
\hline
\end{tabular}


Table 5 Forecast accuracy for subsamples partitioned by forecast horizon, fiscal year, and country

This table presents ordinary least squares regression results of forecast accuracy on local analyst dummy and analyst, forecast and firm characteristics for the subsamples partitioned by forecast horizon, by year, and by country. Horizon zero refers to forecasts provided within 180 days after the fiscal year end but at least 5 days before the reporting dates of actual earnings according to $\mathrm{I} / \mathrm{B} / \mathrm{E} / \mathrm{S}$. Horizon one refers to forecasts provided within one year before the fiscal year end. The dependent variable (Pmafep) is computed as Pmafep $_{\mathrm{ijt}}=\left(\mathrm{AFEP}_{\mathrm{ijt}}{ }^{-}\right.$ $\operatorname{avgAFEP}_{\mathrm{jT}} / \mathrm{avgAFEP}_{\mathrm{jT}}$ where $\mathrm{AFEP}_{\mathrm{ijt}}$ is the absolute forecast error by analyst $\mathrm{i}$ for firm $\mathrm{j}$ at time $\mathrm{t}$ scaled by the latest available monthly stock price and avgAFEP $\mathrm{j}_{\mathrm{j}}$ is the mean absolute forecast error of all of the forecasts for firm $\mathrm{j}$ for fiscal year T. To facilitate interpretation, we multiply this variable by minus one, so that higher values of the dependent variable imply more accurate forecasts. All variables are as defined in Table 2. Independent variables are demeaned by the firm/year averages to reduce heteroskedasticity. T-statistics adjusted for firm-level clustering are in parentheses.

\begin{tabular}{|c|c|c|c|c|c|}
\hline \multirow{2}{*}{ Variables } & \multicolumn{2}{|c|}{ Horizon } & \multicolumn{3}{|c|}{ Year } \\
\hline & 0 & 1 & 2001 & 2002 & 2003 \\
\hline $\begin{array}{l}\text { Dummy for } \\
\text { local analysts }\end{array}$ & $\begin{array}{r}0.071 \\
(2.78)\end{array}$ & $\begin{array}{c}0.034 \\
(2.76)\end{array}$ & $\begin{array}{r}0.063 \\
(3.39)\end{array}$ & $\begin{array}{r}0.029 \\
(1.63)\end{array}$ & $\begin{array}{r}0.034 \\
(1.83)\end{array}$ \\
\hline Broker size & $\begin{array}{l}-0.004 \\
(-0.32)\end{array}$ & $\begin{array}{c}0.009 \\
(1.42)\end{array}$ & $\begin{array}{r}0.002 \\
(0.18)\end{array}$ & $\begin{array}{r}0.009 \\
(0.84)\end{array}$ & $\begin{array}{r}0.010 \\
(1.03)\end{array}$ \\
\hline Forecast horizon & $\begin{array}{l}-0.419 \\
(-3.29)\end{array}$ & $\begin{array}{r}-0.673 \\
(-17.24)\end{array}$ & $\begin{array}{r}-0.748 \\
(-12.70)\end{array}$ & $\begin{array}{l}-0.483 \\
(-8.47)\end{array}$ & $\begin{array}{l}-0.472 \\
(-8.05)\end{array}$ \\
\hline $\begin{array}{l}\text { Number of industries } \\
\text { covered }\end{array}$ & $\begin{array}{l}-0.003 \\
(-0.60)\end{array}$ & $\begin{array}{c}0.000 \\
(0.17)\end{array}$ & $\begin{array}{r}0.001 \\
(0.45)\end{array}$ & $\begin{array}{r}0.003 \\
(0.82)\end{array}$ & $\begin{array}{r}-0.004 \\
(-1.18)\end{array}$ \\
\hline $\begin{array}{l}\text { Firm-specific } \\
\text { experience }\end{array}$ & $\begin{array}{r}0.010 \\
(1.40)\end{array}$ & $\begin{array}{r}0.007 \\
(1.58)\end{array}$ & $\begin{array}{r}0.016 \\
(2.42)\end{array}$ & $\begin{array}{r}0.005 \\
(0.81)\end{array}$ & $\begin{array}{r}0.005 \\
(0.78)\end{array}$ \\
\hline Career experience & $\begin{array}{l}-0.010 \\
(-2.13)\end{array}$ & $\begin{array}{l}-0.009 \\
(-3.39)\end{array}$ & $\begin{array}{l}-0.012 \\
(-2.64)\end{array}$ & $\begin{array}{l}-0.009 \\
(-1.86)\end{array}$ & $\begin{array}{l}-0.009 \\
(-2.41)\end{array}$ \\
\hline Constant & $\begin{array}{r}-0.031 \\
(-0.88)\end{array}$ & $\begin{array}{r}0.049 \\
(6.00)\end{array}$ & $\begin{array}{r}0.007 \\
(0.62)\end{array}$ & $\begin{array}{r}0.029 \\
(2.35)\end{array}$ & $\begin{array}{r}0.017 \\
(1.56)\end{array}$ \\
\hline No. of obs & 4,528 & 15,693 & 6,598 & 6,507 & 7,116 \\
\hline Adjusted $\mathrm{R}^{2}$ & 0.006 & 0.055 & 0.074 & 0.033 & 0.026 \\
\hline
\end{tabular}




\begin{tabular}{|c|c|c|c|c|}
\hline \multicolumn{5}{|c|}{ By country } \\
\hline Country & Coef. for local & t-statistic & No. of obs & Adjusted $\mathrm{R}^{2}$ \\
\hline Argentina & 0.663 & 2.17 & 48 & 0.157 \\
\hline Australia & -0.088 & -0.73 & 265 & 0.060 \\
\hline Austria & -0.325 & -0.67 & 44 & 0.093 \\
\hline Belgium & 0.323 & 2.62 & 201 & 0.097 \\
\hline Brazil & 0.067 & 0.89 & 471 & 0.064 \\
\hline Chile & 0.046 & 0.20 & 52 & 0.250 \\
\hline China & 0.347 & 1.90 & 208 & 0.073 \\
\hline Denmark & 0.382 & 2.49 & 244 & 0.036 \\
\hline Finland & -0.081 & -0.53 & 184 & 0.033 \\
\hline France & 0.017 & 0.51 & 2,569 & 0.029 \\
\hline Germany & 0.088 & 1.98 & 1,794 & 0.050 \\
\hline Hong Kong & -0.016 & -0.18 & 558 & 0.134 \\
\hline India & 0.308 & 3.41 & 287 & 0.080 \\
\hline Indonesia & 0.355 & 2.96 & 159 & 0.190 \\
\hline Ireland & 0.106 & 0.48 & 152 & 0.027 \\
\hline Italy & 0.066 & 1.38 & 1,091 & 0.040 \\
\hline Japan & 0.199 & 3.04 & 834 & 0.148 \\
\hline Korea & 0.240 & 1.86 & 103 & 0.275 \\
\hline Malaysia & 0.029 & 0.47 & 614 & 0.164 \\
\hline Mexico & -0.159 & -1.58 & 267 & 0.051 \\
\hline Netherlands & 0.011 & 0.22 & 1,335 & 0.064 \\
\hline Norway & -0.309 & -1.31 & 103 & 0.110 \\
\hline Philippines & 0.124 & 0.86 & 131 & 0.118 \\
\hline Portugal & 0.126 & 0.75 & 187 & 0.078 \\
\hline Singapore & 0.170 & 1.83 & 316 & 0.099 \\
\hline South Africa & 0.307 & 1.57 & 59 & 0.100 \\
\hline Spain & 0.045 & 0.73 & 773 & 0.037 \\
\hline Sweden & 0.076 & 1.17 & 857 & 0.037 \\
\hline Switzerland & 0.079 & 1.17 & 952 & 0.057 \\
\hline Taiwan & 0.063 & 0.85 & 480 & 0.320 \\
\hline Thailand & 0.032 & 0.38 & 362 & 0.203 \\
\hline The U.K. & 0.014 & 0.53 & 4,521 & 0.013 \\
\hline
\end{tabular}


Table 6 Local analyst advantage and firm-level corporate governance

This table presents ordinary least squares regression results of forecast accuracy on local analyst dummy, analyst, firm and forecast characteristics, and governance variables. Three proxies for firm-level governance are used: S\&P's Transparency and Disclosure Score (tdscore), dummy for large firm (mvdum), and dummy for a firm with ADR program. Dependent variable (Pmafep) is computed Pmafep $\mathrm{p}_{\mathrm{ijt}}=\left(\mathrm{AFEP}_{\mathrm{ijt}} \mathrm{avgAFEP}_{\mathrm{jT}}\right) / \mathrm{avgAFEP}_{\mathrm{jT}}$ where $\mathrm{AFEP}_{\mathrm{ijt}}$ is the absolute forecast error by analyst $i$ for firm $j$ at time $t$ scaled by the latest available monthly stock price and $\operatorname{avgAFEP}_{\mathrm{jT}}$ is the mean absolute forecast error of all of the forecasts for firm $\mathrm{j}$ for fiscal year $\mathrm{T}$. To facilitate interpretation, we multiply this variable by minus one, so that higher values of dependent variable imply more accurate forecasts. All variables are as defined in Table 2. Independent variables are demeaned by the firm/year averages to reduce heteroskedasticity. T-statistics adjusted for firm-level clustering are in parentheses.

\begin{tabular}{|c|c|c|c|}
\hline Variables & (1) & (2) & (3) \\
\hline $\begin{array}{l}\text { Dummy for } \\
\text { local analysts (a) }\end{array}$ & $\begin{array}{r}0.064 \\
(3.68)\end{array}$ & $\begin{array}{r}0.046 \\
(3.08)\end{array}$ & $\begin{array}{r}0.062 \\
(4.20)\end{array}$ \\
\hline Dummy for transparency (b) & $\begin{array}{r}0.019 \\
(1.38)\end{array}$ & & \\
\hline$(a) *(b)$ & $\begin{array}{l}-0.038 \\
(-1.73)\end{array}$ & & \\
\hline Dummy for firm size (c) & & $\begin{array}{r}0.030 \\
(2.20)\end{array}$ & \\
\hline (a) $*(c)$ & & $\begin{array}{l}-0.004 \\
(-0.17)\end{array}$ & \\
\hline Dummy for $A D R$ firm (d) & & & $\begin{array}{r}0.025 \\
(1.92)\end{array}$ \\
\hline$(a) *(d)$ & & & $\begin{array}{l}-0.036 \\
(-1.64)\end{array}$ \\
\hline Broker size & $\begin{array}{r}0.007 \\
(1.27)\end{array}$ & $\begin{array}{r}0.007 \\
(1.26)\end{array}$ & $\begin{array}{r}0.007 \\
(1.27)\end{array}$ \\
\hline Forecast horizon & $\begin{array}{r}-0.569 \\
(-15.54)\end{array}$ & $\begin{array}{r}-0.570 \\
(-15.58)\end{array}$ & $\begin{array}{r}-0.570 \\
(-15.55)\end{array}$ \\
\hline $\begin{array}{l}\text { Number of industries } \\
\text { covered }\end{array}$ & $\begin{array}{r}0.000 \\
(0.05)\end{array}$ & $\begin{array}{r}0.000 \\
(0.06)\end{array}$ & $\begin{array}{r}0.000 \\
(0.08)\end{array}$ \\
\hline $\begin{array}{l}\text { Firm-specific } \\
\text { experience }\end{array}$ & $\begin{array}{r}0.007 \\
(2.01)\end{array}$ & $\begin{array}{r}0.007 \\
(2.01)\end{array}$ & $\begin{array}{l}0.008 \\
(2.03)\end{array}$ \\
\hline Career experience & $\begin{array}{l}-0.010 \\
(-3.84)\end{array}$ & $\begin{array}{r}-0.010 \\
(-3.84)\end{array}$ & $\begin{array}{r}-0.010 \\
(-3.84)\end{array}$ \\
\hline Constant & $\begin{array}{c}0.008 \\
(0.66)\end{array}$ & $\begin{array}{r}0.003 \\
(0.28)\end{array}$ & $\begin{array}{r}0.004 \\
(0.43)\end{array}$ \\
\hline No. of obs & 20,221 & 20,221 & 20,221 \\
\hline Adjusted $\mathrm{R}^{2}$ & 0.043 & 0.043 & 0.043 \\
\hline
\end{tabular}


Table 7 Local analyst advantage and country characteristics

This table presents ordinary least squares regression results of forecast error on local analyst dummy, analyst, firm and forecast characteristics, and country characteristics. Country characteristic variables include variables related to culture, degree of economic and financial development, degree of foreign portfolio investment, degree of investor protection, transparency and disclosure, and private information acquisition and communication. Dependent variable (Pmafep) is computed Pmafep $\mathrm{p}_{\mathrm{jj}}=\left(\mathrm{AFEP}_{\mathrm{ijt}} \mathrm{avgAFEP}_{\mathrm{jT}}\right) / \mathrm{avgAFEP}_{\mathrm{jT}}$ where $\mathrm{AFEP}_{\mathrm{ijt}}$ is the absolute forecast error by analyst $i$ for firm $j$ at time $t$ scaled by the latest available monthly stock price and avgAFEP ${ }_{j \mathrm{~T}}$ is the mean absolute forecast error of all of the forecasts for firm $\mathrm{j}$ for fiscal year $\mathrm{T}$. To facilitate interpretation, we multiply this variable by minus one, so that higher values of dependent variable imply more accurate forecasts. All country characteristic variables are as defined in Table 2. The regressions include the same controlling variables as in Table 5 and are not reported for brevity. T-statistics adjusted for firm-level clustering are in parentheses.

\begin{tabular}{|c|c|c|c|c|c|c|}
\hline \multirow[b]{2}{*}{ Model } & \multirow[b]{2}{*}{$\begin{array}{l}\text { Country } \\
\text { characteristics }\end{array}$} & \multicolumn{5}{|c|}{ Local dummy } \\
\hline & & $\begin{array}{l}\text { Local } \\
\text { dummy }\end{array}$ & $\begin{array}{c}\text { Country } \\
\text { Characteristic } \\
\text { variable }\end{array}$ & $\begin{array}{c}\mathrm{x} \\
\text { Country } \\
\text { Characteristic } \\
\text { variable } \\
\end{array}$ & $\begin{array}{l}\text { Number of } \\
\text { observations }\end{array}$ & Adj. $R^{2}$ \\
\hline (1) & English language & $\begin{array}{r}0.058 \\
(4.16)\end{array}$ & $\begin{array}{r}-0.009 \\
(-0.48)\end{array}$ & $\begin{array}{l}-0.026 \\
(-0.98)\end{array}$ & 20,221 & 0.043 \\
\hline (2) & GDP per capita & $\begin{array}{r}0.069 \\
(3.47)\end{array}$ & $\begin{array}{r}0.033 \\
(2.52)\end{array}$ & $\begin{array}{l}-0.037 \\
(-1.54)\end{array}$ & 19,741 & 0.038 \\
\hline (3) & Developed market & $\begin{array}{r}0.065 \\
(2.85)\end{array}$ & $\begin{array}{r}0.023 \\
(1.48)\end{array}$ & $\begin{array}{l}-0.026 \\
(-1.00)\end{array}$ & 20,221 & 0.043 \\
\hline (4) & Equity market & $\begin{array}{r}0.062 \\
(3.23)\end{array}$ & $\begin{array}{r}0.014 \\
(0.97)\end{array}$ & $\begin{array}{l}-0.032 \\
(-1.30)\end{array}$ & 19,175 & 0.043 \\
\hline (5) & State ownership & $\begin{array}{r}0.024 \\
(1.50)\end{array}$ & $\begin{array}{l}-0.011 \\
(-0.77)\end{array}$ & $\begin{array}{r}0.040 \\
(1.60)\end{array}$ & 15,110 & 0.044 \\
\hline (6) & $\begin{array}{l}\text { Foreign bank } \\
\text { ownership }\end{array}$ & $\begin{array}{l}0.080 \\
(3.86)\end{array}$ & $\begin{array}{c}0.006 \\
(0.33)\end{array}$ & $\begin{array}{l}-0.034 \\
(-1.03)\end{array}$ & 8,785 & 0.050 \\
\hline (7) & $\begin{array}{l}\text { Ownership } \\
\text { concentration }\end{array}$ & $\begin{array}{r}0.027 \\
(1.85)\end{array}$ & $\begin{array}{l}-0.016 \\
(-1.20)\end{array}$ & $\begin{array}{r}0.045 \\
(2.02)\end{array}$ & 20,013 & 0.043 \\
\hline (8) & Pooled investment & $\begin{array}{r}0.112 \\
(4.22)\end{array}$ & $\begin{array}{l}0.048 \\
(3.39)\end{array}$ & $\begin{array}{l}-0.098 \\
(-3.22)\end{array}$ & 16,141 & 0.028 \\
\hline (9) & Legal origin & $\begin{array}{c}0.032 \\
(1.61)\end{array}$ & $\begin{array}{r}0.007 \\
(0.41)\end{array}$ & $\begin{array}{r}0.029 \\
(1.14)\end{array}$ & 20,221 & 0.043 \\
\hline (10) & Antidirector rights & $\begin{array}{r}0.053 \\
(3.26)\end{array}$ & $\begin{array}{l}-0.06 \\
(-1.60)\end{array}$ & $\begin{array}{l}-0.002 \\
(-0.10)\end{array}$ & 20,013 & 0.043 \\
\hline (11) & Property rights & $\begin{array}{r}0.068 \\
(3.50)\end{array}$ & $\begin{array}{l}0.032 \\
(2.36)\end{array}$ & $\begin{array}{l}-0.036 \\
(-1.52)\end{array}$ & 20,013 & 0.043 \\
\hline (12) & Public enforcement & $\begin{array}{c}0.066 \\
(3.72)\end{array}$ & $\begin{array}{l}-0.011 \\
(-0.81)\end{array}$ & $\begin{array}{l}-0.027 \\
(-1.15)\end{array}$ & 20,013 & 0.043 \\
\hline (13) & Class action & $\begin{array}{r}0.075 \\
(4.81)\end{array}$ & $\begin{array}{r}0.011 \\
(0.82)\end{array}$ & $\begin{array}{l}-0.053 \\
(-2.36)\end{array}$ & 20,013 & 0.043 \\
\hline
\end{tabular}




\begin{tabular}{|c|c|c|c|c|c|c|}
\hline \multirow[b]{2}{*}{ Model } & \multirow[b]{2}{*}{$\begin{array}{l}\text { Country } \\
\text { characteristics }\end{array}$} & \multirow[b]{2}{*}{$\begin{array}{l}\text { Local } \\
\text { dummy }\end{array}$} & \multicolumn{3}{|c|}{ Local dummy } & \multirow[b]{2}{*}{ Adj. $R^{2}$} \\
\hline & & & $\begin{array}{c}\text { Country } \\
\text { Characteristic } \\
\text { variable }\end{array}$ & $\begin{array}{c}\mathrm{x} \\
\text { Country } \\
\text { Characteristic } \\
\text { variable } \\
\end{array}$ & $\begin{array}{l}\text { Number of } \\
\text { observations }\end{array}$ & \\
\hline (14) & $\begin{array}{l}\text { Insider trading } \\
\text { enforcement }\end{array}$ & $\begin{array}{r}0.058 \\
(2.58)\end{array}$ & $\begin{array}{r}0.022 \\
(1.55)\end{array}$ & $\begin{array}{l}-0.023 \\
(-0.89)\end{array}$ & 19,854 & 0.043 \\
\hline (15) & $\begin{array}{l}\text { Earnings } \\
\text { management }\end{array}$ & $\begin{array}{r}0.017 \\
(1.09)\end{array}$ & $\begin{array}{l}-0.023 \\
(-1.60)\end{array}$ & $\begin{array}{r}0.068 \\
(2.97)\end{array}$ & 19,175 & 0.044 \\
\hline (16) & CIFAR & $\begin{array}{r}0.081 \\
(4.90)\end{array}$ & $\begin{array}{l}0.026 \\
(1.94)\end{array}$ & $\begin{array}{l}-0.061 \\
(-2.72)\end{array}$ & 19,854 & 0.043 \\
\hline (17) & $\mathrm{R}^{2} \_$Morck & $\begin{array}{l}0.026 \\
(1.89)\end{array}$ & $\begin{array}{l}-0.043 \\
(-2.96)\end{array}$ & $\begin{array}{r}0.056 \\
(2.41)\end{array}$ & 18,746 & 0.043 \\
\hline
\end{tabular}




\section{Table 8 Foreign investors and local analyst advantage}

This table presents ordinary least squares regression results of forecast error on local analyst dummy, analyst, firm and forecast characteristics, and foreign investment. Variables that proxy for the degree of foreign investment and demand for analyst services by foreign investors include (1) dummy variable that takes value 1 if a country's U.S holdings of equity and debt scaled by local market GDP is greater than the median of the sample countries (US holdings), (2) dummy variable that takes value 1 if a country's U.S. flow of equity and debt scaled by local market GDP is greater than the median of the sample countries (US flow), (3) the fraction of the equity market capitalization held by U.S. investors (US equity), (4) the share of a country's equities in the portfolio of U.S. investors (US portfolio), (5) a country's share in the world market portfolio (WORLD RATIO), and (6) the difference between a country's share in the world market portfolio and the country's share in the portfolio of U.S. investors (DIFF). Dependent variable (Pmafep) is computed Pmafep $_{\mathrm{ijt}}=\left(\mathrm{AFEP}_{\mathrm{ijt}} \mathrm{avgAFEP}_{\mathrm{jT}}\right) / \mathrm{avgAFEP}_{\mathrm{jT}}$ where $\mathrm{AFEP}_{\mathrm{ijt}}$ is the absolute forecast error by analyst $\mathrm{i}$ for firm $\mathrm{j}$ at time $\mathrm{t}$ scaled by the latest available monthly stock price and avgAFEP ${ }_{\mathrm{jT}}$ is the mean absolute forecast error of all of the forecasts for firm $\mathrm{j}$ for fiscal year $\mathrm{T}$. To facilitate interpretation, we multiply this variable by minus one, so that higher values of dependent variable imply more accurate forecasts. All country characteristic variables are as defined in Table 2 . The regressions include the same control variables as in Table 5 and are not reported for brevity. T-statistics adjusted for firm-level clustering are in parentheses.

\begin{tabular}{|c|c|c|c|c|c|c|}
\hline Model & $\begin{array}{l}\text { Country } \\
\text { characteristics that } \\
\text { proxy for foreign } \\
\text { investment }\end{array}$ & $\begin{array}{c}\text { Local } \\
\text { dummy }\end{array}$ & $\begin{array}{c}\text { Country } \\
\text { Characteristic } \\
\text { variable }\end{array}$ & $\begin{array}{c}\text { Local dummy } \\
\mathrm{x} \\
\text { Country } \\
\text { Characteristic } \\
\text { variable } \\
\end{array}$ & $\begin{array}{l}\text { Number of } \\
\text { observations }\end{array}$ & Adj. $R^{2}$ \\
\hline (1) & US holdings & $\begin{array}{r}0.097 \\
(5.54)\end{array}$ & $\begin{array}{r}0.054 \\
(3.93)\end{array}$ & $\begin{array}{l}-0.078 \\
(-3.49)\end{array}$ & 20,221 & 0.044 \\
\hline (2) & US flows & $\begin{array}{c}0.085 \\
(4.21)\end{array}$ & $\begin{array}{r}0.042 \\
(3.15)\end{array}$ & $\begin{array}{l}-0.057 \\
(-2.38)\end{array}$ & 19,741 & 0.039 \\
\hline (3) & US equity & $\begin{array}{r}0.079 \\
(4.65)\end{array}$ & $\begin{array}{r}0.001 \\
(2.74)\end{array}$ & $\begin{array}{l}-0.002 \\
(-2.77)\end{array}$ & 20,221 & 0.043 \\
\hline (4) & US portfolio & $\begin{array}{r}0.071 \\
(4.65)\end{array}$ & $\begin{array}{r}0.001 \\
(0.73)\end{array}$ & $\begin{array}{r}-0.003 \\
(-2.07)\end{array}$ & 20,221 & 0.043 \\
\hline (5) & WORLD RATIO & $\begin{array}{r}0.067 \\
(4.28)\end{array}$ & $\begin{array}{r}0.001 \\
(0.09)\end{array}$ & $\begin{array}{c}-0.002 \\
(-1.53)\end{array}$ & 20,221 & 0.043 \\
\hline (6) & $\begin{array}{l}\text { DIFF (WORLD } \\
\text { RATIO - US } \\
\text { portfolio) }\end{array}$ & $\begin{array}{l}0.048 \\
(4.46)\end{array}$ & $\begin{array}{l}-0.011 \\
(-2.67)\end{array}$ & $\begin{array}{r}0.019 \\
(3.05)\end{array}$ & 20,221 & 0.044 \\
\hline (7) & WORLD RATIO & $\begin{array}{r}0.065 \\
(4.10)\end{array}$ & $\begin{array}{c}-0.001 \\
(-0.36)\end{array}$ & $\begin{array}{l}-0.001 \\
(-0.91)\end{array}$ & 20,221 & 0.044 \\
\hline & DIFF & & $\begin{array}{l}-0.011 \\
(-2.67)\end{array}$ & $\begin{array}{c}0.016 \\
(2.45)\end{array}$ & & \\
\hline
\end{tabular}


Table 9 Robustness tests

The table presents the results of robustness tests using different proxies for forecast accuracies and different samples. Models (1) through (3) use alternative proxies for forecast errors as dependent variables. Model (1) uses 'pmafe' as dependent variable, Model (2) 'dafep', and Model (3) 'range'. All variables are defined in Table 2 and rescaled such that higher values indicate more accurate forecasts. Model (4) is estimated for the sample that does not impose restriction that a firm is followed by both local and foreign analysts. Model (5) is estimated for the sample that contains all the annual earnings forecasts that analysts provide for the firms they cover over 2001-2003. Model (6) adds additional control variables that may affect forecast accuracy. Independent variables are demeaned by the firm/year averages to reduce heteroskedasticity. All models are estimated with ordinary least squares regressions except Model (3) that uses random effect regression at the firm-level. T-statistics adjusted for firm-level clustering are in parentheses.

\begin{tabular}{|c|c|c|c|c|c|c|}
\hline & $(1)$ & (2) & (3) & (4) & $(5)$ & (6) \\
\hline $\begin{array}{l}\text { Dummy for } \\
\text { local analysts }\end{array}$ & $\begin{array}{r}0.039 \\
(3.68)\end{array}$ & $\begin{array}{r}0.001 \\
(2.27)\end{array}$ & $\begin{array}{r}0.010 \\
(2.15)\end{array}$ & $\begin{array}{r}0.032 \\
(3.50)\end{array}$ & $\begin{array}{r}0.019 \\
(2.31)\end{array}$ & $\begin{array}{r}0.040 \\
(3.67)\end{array}$ \\
\hline Broker size & $\begin{array}{r}0.005 \\
(0.89)\end{array}$ & $\begin{array}{c}0.002 \\
(1.27)\end{array}$ & $\begin{array}{r}0.003 \\
(1.32)\end{array}$ & $\begin{array}{c}0.009 \\
(1.76)\end{array}$ & $\begin{array}{r}0.279 \\
(0.72)\end{array}$ & $\begin{array}{r}0.007 \\
(1.24)\end{array}$ \\
\hline Forecast horizon & $\begin{array}{r}-0.730 \\
(-20.15)\end{array}$ & $\begin{array}{r}-0.010 \\
(-10.43)\end{array}$ & $\begin{array}{r}-0.162 \\
(-21.12)\end{array}$ & $\begin{array}{r}-0.615 \\
(-18.40)\end{array}$ & $\begin{array}{r}-0.679 \\
(-25.46)\end{array}$ & $\begin{array}{r}-0.555 \\
(-15.06)\end{array}$ \\
\hline $\begin{array}{l}\text { Number of industries } \\
\text { covered }\end{array}$ & $\begin{array}{c}0.000 \\
(0.01)\end{array}$ & $\begin{array}{c}0.000 \\
(0.85)\end{array}$ & $\begin{array}{r}0.000 \\
(0.35)\end{array}$ & $\begin{array}{r}0.001 \\
(0.54)\end{array}$ & $\begin{array}{r}-0.317 \\
(-2.27)\end{array}$ & $\begin{array}{r}0.002 \\
(0.64)\end{array}$ \\
\hline $\begin{array}{l}\text { Firm-specific } \\
\text { experience }\end{array}$ & $\begin{array}{c}0.008 \\
(2.22)\end{array}$ & $\begin{array}{c}0.000 \\
(0.57)\end{array}$ & $\begin{array}{c}0.002 \\
(1.20)\end{array}$ & $\begin{array}{c}0.008 \\
(2.40)\end{array}$ & $\begin{array}{r}1.019 \\
(4.06)\end{array}$ & $\begin{array}{r}0.007 \\
(1.81)\end{array}$ \\
\hline Career experience & $\begin{array}{c}-0.010 \\
(-3.98)\end{array}$ & $\begin{array}{l}-0.001 \\
(-1.39)\end{array}$ & $\begin{array}{l}-0.003 \\
(-3.95)\end{array}$ & $\begin{array}{l}-0.010 \\
(-4.52)\end{array}$ & $\begin{array}{l}-0.537 \\
(-2.72)\end{array}$ & $\begin{array}{r}-0.009 \\
(-3.78)\end{array}$ \\
\hline $\begin{array}{l}\text { Number of forecasts } \\
\text { made }\end{array}$ & & & & & & $\begin{array}{r}0.001 \\
(2.81)\end{array}$ \\
\hline $\begin{array}{l}\text { Number of firms } \\
\text { covered }\end{array}$ & & & & & & $\begin{array}{r}-0.002 \\
(-1.27)\end{array}$ \\
\hline $\begin{array}{l}\text { Number of countries } \\
\text { covered }\end{array}$ & & & & & & $\begin{array}{r}-0.006 \\
(-1.38)\end{array}$ \\
\hline constant & $\begin{array}{c}0.018 \\
(2.82)\end{array}$ & $\begin{array}{r}0.001 \\
(4.24)\end{array}$ & $\begin{array}{r}0.674 \\
(148.52)\end{array}$ & $\begin{array}{r}0.020 \\
(3.03)\end{array}$ & $\begin{array}{c}0.038 \\
(6.24)\end{array}$ & $\begin{array}{r}0.019 \\
(2.86)\end{array}$ \\
\hline No. of obs & 20,056 & 20,221 & 19,008 & 25,615 & 63,617 & 20,221 \\
\hline Adjusted $\mathrm{R}^{2}$ & 0.070 & 0.020 & 0.020 & 0.048 & 0.101 & 0.043 \\
\hline
\end{tabular}

